\title{
Clinical and pathological aspects of condyloma acuminatum - review of literature and case presentation
}

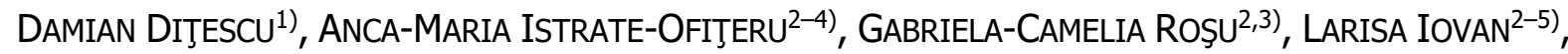 \\ ILONA MiHAELA LILIAC ${ }^{2,3,5)}$, GEORGE-LUCIAN ZORILĂ ${ }^{4)}$, MARIA BĂLĂŞOIU6), LILIANA CERCELARU7) \\ 1) Department of Obstetrics and Gynecology, Constantin Brâncuşi University of Târgu Jiu, Romania \\ 2) Department of Histology, University of Medicine and Pharmacy of Craiova, Romania \\ 3) Research Center for Microscopic Morphology and Immunology, University of Medicine and Pharmacy \\ of Craiova, Romania \\ 4) Department of Obstetrics and Gynecology, University of Medicine and Pharmacy of Craiova, Romania \\ 5) PhD Student, Doctoral School, University of Medicine and Pharmacy of Craiova, Romania \\ 6) Department of Microbiology, University of Medicine and Pharmacy of Craiova, Romania \\ 7) Department of Anatomy, University of Medicine and Pharmacy of Craiova, Romania
}

\begin{abstract}
Condyloma acuminatum (CA) is a pathology caused by the human papillomavirus (HPV). It is manifested by the appearance of warts in the vulvar, pubic, and anorectal regions, but can occur in other areas. It is a common disease that can be prevented by using measures such as condoms or vaccine. Topical, local, pharmacological, surgical, and excisional therapy options are available for this pathology. Macroscopically, it appears as a vegetative tumor, with a single implantation base that branches towards the periphery, with a cauliflower appearance. CA is defined microscopically by acanthosis, parakeratosis, papillomatosis and koilocytosis. Immunohistochemical studies can detect the presence of various HPV strains or viral antigens and can emphasize certain specific characteristics; e.g., in the case presented in this study, we observed that the tumor had a fulminant evolution due to a strong vascular base identified with anti-cluster of differentiation (CD) 34 antibody, by the existence of epithelial cells with a high degree of cell proliferation, as evidenced by the anti-Ki67 antibody, the inactivation of the tumor suppressor gene and the appearance of immunolabeling for the anti-p53 antibody, by the strong immunoreactivity for p63 which reveals the existence of cells with dysplastic and neoplastic transformation potential, but also by detecting the immunolabeling for p16 ${ }^{\text {INK4a }}$ that is associated with the existence of HPV. Also, the tumor was immunoreactive for cytokeratin (CK) AE1/AE3, partially immunoreactive for CK5/6 in the basal layer and negative for CK7, which demonstrates the squamous epithelial origin of the described tumor. Subepithelial cells of the inflammatory system have been identified, such as macrophages immunolabeled with anti-CD68 antibody, T-lymphocytes immunolabeled with anti-CD3 antibody and rare B-lymphocytes immunolabeled with anti-CD20 antibody, which demonstrates the strong cellular response to remove the virus from the structure. Surgical and excisional treatment was helpful for the patient, because she was able to resume normal sexual activity and defecation, and on the other hand, microscopic studies showed the potential for malignant transformation of CA.
\end{abstract}

Keywords: condyloma acuminatum, HPV, histopathology, immunohistochemistry.

\section{a Introduction}

Condyloma acuminatum (CA) is a predominantly sexually transmitted disease (STD) that is characterized by the appearance of fleshy papules and skin-colored in the anorectal region and is caused by infection with several strains of human papillomavirus (HPV). These formations are also called venereal warts, anal warts or anogenital warts [1].

In 1907, CA was classified as a cutaneous manifestation of syphilis or gonorrhea, but other authors used cell-free transmission experiments to demonstrate the virus' infectious nature, injecting wart extracts into previously uninfected skin and observing the appearance of papillomatous eruptions in those locations [2].

Subsequent experiments and studies have shown that genital warts are benign proliferations of anogenital mucosa, caused by a viral HPV infection, recently detected by molecular biology studies [3].

\section{Aim}

The aims of this study were to emphasize the clinical and morphopathological characteristics of CA as described in the literature and to highlight the serious importance of prevention and effective therapy.

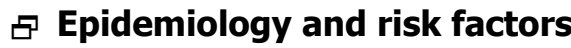

In the United States (US), genital HPV infections affect roughly $10-20 \%$ of the population, representing about 20 million people $[4,5]$, whereas clinical signs occur in $1 \%$ of the infected population.

Since 1975, the incidence of this disease has been increasing in the US, with onset ages ranging from 17 to 33 years in $80 \%$ of cases [6]. The use of the medication can cause the condylomas to disappear, but the cause cannot be determined, thus the likelihood of recurrence is considerable (50-73\%) [4]. Warts, on the other hand, can regress spontaneously without therapy [6].

This is an open-access article distributed under the terms of a Creative Commons Attribution-NonCommercial-ShareAlike 4.0 International Public License, which permits unrestricted use, adaptation, distribution and reproduction in any medium, non-commercially, provided the new creations are licensed under identical terms as the original work and the original work is properly cited. 
According to some research, the virus can survive in the human body for the rest of one's life, but other studies based on sensitive deoxyribonucleic acid (DNA) techniques have revealed that the patient's immune system can respond in such a way that the virus is removed or suppressed at a level that cannot be detected by polymerase chain reaction (PCR) tests. The PCR tests also detected subclinical stages with a prevalence of $10 \%$ [6].

$\mathrm{CA}$ is one of the most frequent types of STD that can affect the general population [7]. In the US, between 500000 and 1000000 new cases with clinical manifestation are detected each year [8, 9]. In 2004, the cost of caring for patients with HPV, CA, or invasive cervical cancer was assessed to be around four billion dollars [10].

This phenomenon of increasing CA cases is inversely related to the age of onset of sexual activity and highly related to the number of sexual partners, with roughly half of new infections occurring in young adults aged 15 to 24 years [3].

HPV is a highly contagious virus that is spread primarily by sexual, anal, and genital contact, but also through vertical transmission or autoinoculation in rare circumstances [11]. As a result of unprotected sexual contact with a person infected with HPV, there is a risk of transmission of approximately $75 \%$, increasing the risk of developing lifelong CA by $50 \%$ in sexually active individuals.

CA-associated risk factors are unprotected sex, STDs, immunosuppression, especially in patients with human immunodeficiency virus (HIV) and use of oral contraceptives or smoking $[12,13]$.

Several studies have demonstrated that the use of condoms can help to reduce viral transmission [14]. Other research has found that condoms are ineffective at preventing viral transmission of strains that cause CA, but they may be more beneficial for men than for women [15].

Because the viral strains that cause CA are extremely contagious, $3 / 4$ of unaffected people who have a partner who is infected develop this pathology within eight months of being infected [15]. Additionally, the presence of warts indicates the degree of infectivity, so the correlation between the presence of warts and the transmission is directly proportional [14]. Another mode of transmission is direct, which occurs during birth if the mother has warts in the vaginal area, or self-inoculation, which happens when the warts are touched with other parts of the body, particularly the hands [15].

Studies have reported that the virus can be transmitted through the sharing of swimwear, underwear, or non- sexual touch during routine care, such as changing the baby's diaper. Children's warts are more likely to be caused by cutaneous HPV types than by subtypes 6 and 11 , and the presence of CA in a child's genital anal area may be a sign of sexual abuse [16].

\section{$\square$ Latency and recurrence}

Over $90 \%$ of infected cases heal spontaneously due to the immune system intervention. Infected cells acquire a dormant state and can reappear at months or even years' intervals [17]. During this latency period, the virus can be transmitted to the sexual partner in $70 \%$ of instances. Recurrence of warts in patients with a history of HPV infection can also be caused by reinfection with this virus or a recurrence of a prior infection. According to studies, around a third of cases are recurrent [8].

\section{ㅁ Virology, dermatopathology and pathophysiology}

HPV infection begins with virus inoculation into the epithelial structure via microabrasions. HPV is a part of the Papovaviridae family of non-enveloped, double-stranded DNA (dsDNA) viruses [18]. Although the virus is capable of penetrating both the mucosal epithelium and the corium of infected tissue, viral replication occurs in the epithelial basal layer, in the structure of cells with tropism, called keratinocytes. The mucosa that is susceptible to HPV infection can be found in the vagina, the cervix, but also in the perianal regions of women and men, in the penile and periurethral areas of men. Viral replication results in the formation of warty papules or warty plaques. HPV's viral genome has six early-open reading frames $(E 1, E 2$, $E 4, E 5, E 6, E 7)$, as well as two late-open reading frames $(L 1, L 2)$. The first ones play a role in regulating and coding of proteins involved in viral replication and determine cell transformation. Furthermore, they are responsible for encoding the proteins contained within the viral capsid [18].

There may be more $L 1$ models that define distinct DNA-virus replication patterns, classifying the virus into additional subtypes. High-risk (HR) HPV strains directly integrate its genetic material into the host cell, resulting in uncontrolled activation of $E 6$ and $E 7$ genes and transcription of oncoproteins and inactivation of $p 53$ and retinoblastoma $(R b)$ tumor suppressor genes, but also cellular proliferation and subsequent evolution toward tumorigenesis (Table 1) [19-21].

Table 1 - Comparison between LR HPV subtypes versus HR HPV subtypes

\begin{tabular}{ccc}
\hline & LR HPV subtypes $\mathbf{6}$ and 11 & HR HPV subtypes 16 and 18 \\
\hline Clinical implications & $\begin{array}{c}\text { 75-90\% cases of CA, respiratory } \\
\text { papillomatosis }\end{array}$ & $\begin{array}{c}\text { 70\% cases of all dysplastic lesions, Bowen's } \\
\text { disease, and invasive cervix cancer }\end{array}$ \\
\hline $\begin{array}{c}\text { Pathophysiological mechanisms } \\
\begin{array}{c}\text { Connections with different types } \\
\text { of verrucous carcinoma }\end{array}\end{array}$ & $\begin{array}{c}\text { Viral DNA undergoes independent viral } \\
\text { replication }\end{array}$ & $\begin{array}{c}\text { Viral DNA integrates into the host genome and } \\
\text { causes inactivation of tumor suppressor genes }\end{array}$ \\
\hline CA: Condyloma acuminatum; DNA: Deoxyribonucleic acid; HPV: Human papillomavirus; HR: High-risk; LR: Low-risk.
\end{tabular}

HPV integration into host cells causes cell infection and the appearance of keratinocytes with altered and atypical morphology, called koilocytes. They contain small nuclei that are eccentrically positioned and the cells having an increased volume. Additionally, a characteristic halo appears perinuclear. Increased epithelial cell volume has a pronounced acanthosis, with the appearance of papillomas, parakeratosis, and hyperkeratosis, as well as the loss of the granular cell layer. The dermis is highly vascularized, with thrombosed capillaries. Moreover, 
infected basal cells migrate to the adjacent layers, amplifying the viral gene. The assembly of virions takes place in the superficial layer of the epithelium, from which they are eliminated to infect their own or foreign adjacent tissues. CA has an exophytic phenotype because of viral effects on epithelial structure [22].

\section{Clinical presentation}

CA does not often cause serious damage to patients, but more severe cases might emerge, obstructing and interrupting the normal functionality of certain anatomical parts due to the increased size of warty tumors. Regarding HPV infection, an incubation period of three to eight months may occur until the onset of clinical manifestations. Clinical signs often manifest 2-3 months following interaction with the source of infection [23]. Occasionally, the virus remains latent, persisting in the epithelial tissue for an extended amount of time without manifesting clinically. According to studies, up to $40 \%$ of cases remain clinically undetected, the virus can be confirmed using DNA tests performed with samples taken from suspected virus-infected locations [24].

Managing a case of CA can also have several implications, involving screening examinations for STDs and HIV, as well as counseling on how to avoid acquiring or spreading STDs, HPV or HIV. Moreover, certain investigations should be performed to detect possible immunosuppression. The patient might be directed into cigarette cessation programs, if necessary. After the onset of clinical manifestations, CA may develop in several regions and increase in size or may regress spontaneously. Around 30\% of CA cases spontaneously regress approximately four months after onset. Unfortunately, long-term remission is not always attainable, and most CA reappears three months after infection, even with adequate therapy [25] The persistence of this infection is facilitated not only by host immunosuppression, but also by HR HPV strains, and viral infection suppression is directly related to the presence of CD4+ cells in the epithelial structure, which play a role in local immune regulation $[25,26]$.

Condylomatous lesions are most frequently found on moist mucous membranes of the anogenital or oral regions following oral sexual contact with an infected partner [9]. They can have a variety of features, such as flat, cauliflower or peduncled form [26]. They can develop individually as solitary keratotic papules or plaques, although they are most commonly seen agglutinated. The clinical presentation begins with flesh-colored papules on the skin measuring $1-2 \mathrm{~mm}$ in diameter, followed by a growth in volume to a few centimeters or even a giant shape. The expansion of these lesions is related to the appearance of pain during sexual intercourse or with the hinder of eutocic birth. The warty appearance of the CA may be variable: it may be white, pink, purplish to reddish-brown colored, flat, warty or cerebriform. Symptoms that may occur are severe discomfort, itching, burning, bleeding on contact with clothing or during intercourse, difficulty urinating or defecating. In men, the lesions appear around the penis or even intraurethral and may be associated with dysuria, hematuria, or active bleeding. Scrotal lesions are extremely rare in immunocompetent organisms. Several patients described an unpleasant smell of secretion from the affected areas $[11,27]$.

\section{a Complications of untreated HPV infection}

Low-risk (LR) HPV strains (6 and 11), but even HR HPV strains (particularly 16 and 18), can cause verrucous carcinoma (VC) with a low degree of differentiation (G3) [28]. VC is classified clinically and pathologically into numerous subtypes based on its anatomical location. If they manifest in the oral cavity, they are called oral florid papillomatosis; if they manifest in the anogenital region, they are called giant condyloma of Buschke and Löwenstein, and if they appear in the palmo-plantar region, they are called carcinoma cuniculatum. All these tumor subtypes are invasive locally but rarely metastasize [29].

\section{口 Positive and differential diagnosis}

CA may be detected with a thorough clinical history and physical examination. The $3-5 \%$ Acetic Acid test may be effective in the subclinical phases for identifying warty lesions that become white in infected areas [30]. The use of anoscopy or colposcopy can aid in the diagnosis of warty lesions [31].

Biopsy in the suspected region is necessary to obtain the correct diagnosis only when lesions with suspected malignancy or an increased risk of malignant transformation are present and are associated with ulceration, immobility, a sudden change in the appearance of the lesion or nonresponse to treatment [27]. Biopsy is performed to detect squamous cell carcinomas (SCCs), such as VC, Bowenoid papulosis (BP), and other similar lesions, but is frequently not required for diagnosis.

Differential diagnosis of CA includes the following entities: molluscum contagiosum, condyloma latum (CL), vulvar papillomatosis, pearly penile papules, angiokeratomas of the scrotum or vulva, skin tags, SCC, BP, seborrheic keratosis [32-35].

Molluscum contagiosum is characterized by the presence of papules that are normally asymptomatic but have a smoother surface than CA and are shaped like a dome, with a central umbilication that may be highlighted by applying a small amount of liquid nitrogen. CL is a manifestation of secondary syphilis that commonly appears as wet, sometimes weepy plaques in the anogenital area. Clinically, patients should be evaluated for further syphilis signs and symptoms. If accessible, darkfield microscopy can be used to visualize spirochetes to differentiate CL from CA. Vulvar papillomatosis is a typical female pathology distinguished by smooth papillary projections that each originate from a distinct base near the vaginal introitus. By contrast, numerous papillary projections can emerge from a single base in CA. Pearly papules penile develop along coronal sulcus and the penile corona in uncircumcised men and can be clinically distinguished from CA by their monomorphic shape and characteristic distribution. Another disease to consider is angiokeratomas of the scrotum or vulva. In contrast to CA, these papules have a distinctive vascular (red or purple) appearance. The skin tag smooth surface and pedunculated appearance usually separate them from CA. SCC is a disease that should be regarded when lesions ulcerate or do not react to commonly effective therapies for $\mathrm{CA}$, or in immunocompromised individuals, or those with atypical lesions. Biopsy is 
indicated in those instances, as described above. BP develops because of HPV 16 infection and has a high probability of progressing to invasive SCC. It presents clinically as flat, but hyperpigmented papules, in contrast to CA. Histopathologically, seborrheic keratosis lacks koilocytes, unlike CA. Giant CA (Buschke-Löwenstein tumor) is a type of VC caused by HPV 6 infection that typically affects the glans penis and appears considerably less frequently on the perianal or vulvar tissue [32-35].

\section{Therapy}

Currently available treatments for CA are primarily focused on removing wart growth rather than eradicating the underlying viral infection. There is limited evidence that current therapies are effective at eradicating longterm genital warts or if they play a significant role in preventing warts from developing into potentially malignant lesions. Currently, a variety of therapies are used, each with a distinct cost, side effect profile, overall effectiveness, and duration of treatment. To date, no therapy has been identified as the best standard of care for CA; alternatively, therapy is chosen according to the particularities of the patient [36]. CA is treated in three main ways: locally [Podophyllotoxin, Imiquimod 5\% cream, Imiquimod 3.75\% cream, Sinecatechins 15\% ointment, Podophyllin, 5-Fluorouracil (5-FU)], surgical and destructive [Trichloroacetic Acid (TCA), cryotherapy, electrosurgery, scissor excision, carbon dioxide $\left(\mathrm{CO}_{2}\right)$ laser], and systemic [Interferon (IFN)] [37].

\section{Podophyllotoxin}

Podophyllotoxin is recommended as $0.05 \%$ solution or gel and $0.15 \%$ cream (Grade A). Podophyllotoxin is a purified extract from the Podophyllum plant that can bind to cellular microtubules, stop mitotic division, and induce wart necrosis within 3-5 days of topical application. As the wart's necrosis, the resulting minor erosions recover within a few days. This therapy is regarded safe and successful even if it is administered by the patient; it is available as a solution, cream or gel and must be administered twice daily, three consecutive days a week, for a maximum of four weeks. Typically, a cream or gel is used to treat vaginal or anal lesions, and a solution is utilized to treat penile lesions $[37,38]$. Podophyllotoxin has a success rate of $45-77 \%$, but a recurrence rate of around $38 \%$, according to studies. Warts which do not heal after four cycles of therapy should be considered for alternative treatment option [39-41].

\section{Imiquimod}

Imiquimod 5\% cream (Grade A) is a topical immunomodulatory agent that can be applied by the patient, and it was firstly used in 1997 to treat external CA. Although its mechanism of action is not clearly known, Imiquimod is thought to activate immune cells by binding to membranous Toll-like receptors $[42,43]$. These changes result in the release of several cytokines such as tumor necrosis factor-alpha (TNF- $\alpha$ ), IFN- $\alpha$ and interleukin-6 (IL-6) factor, which generate an inflammatory response that promotes wart removal. In addition, a decrease in messenger ribonucleic acid (mRNA) expression was observed for CK proliferation markers but also in viral load measured by HPV DNA, in patients treated with Imiquimod [44-46]. For the treatment of CA, Imiquimod is applied three times a week for up to 16 weeks. Although multiple clinical trials have validated the efficacy of Imiquimod $5 \%$ cream treatment for CA treatment, but the prolonged length of treatment may impair patient compliance [47].

Imiquimod 3.75\% cream (Grade A) was recently approved by the Food and Drug Administration (FDA) for the treatment of CA. Although the cure rate is lower than Imiquimod 5\% it is considered that due to the shorter duration of use, patients' compliance is higher. It is applied daily for a maximum of eight weeks. Local side effects are milder than those associated with Imiquimod 5\%, and no systemic adverse effects has been reported [48, 49].

\section{Sinecatechins}

Sinecatechins $15 \%$ ointment (Grade A) is a botanical extract approved by the FDA in 2006 for the treatment of genital warts. The active ingredient is a green tea extract that contains Sinecatechins, which are believed to have antineoplastic, antioxidant and antiviral properties. Although the mechanism of action is unclear, it is believed that it modulates the inflammatory response by inhibiting the activator protein-1 (AP-1) and nuclear factor-kappa B $(\mathrm{NF}-\kappa \mathrm{B})$ transcription factors. Sinecatechins $15 \%$ cream is applied locally on lesions three times a day for up to four weeks. If no improvement is noticed within the first few weeks of treatment, a more intensive kind of treatment is used $[50,51]$.

\section{Trichloroacetic Acid}

TCA $80-90 \%$ solution (Grade B) is a destructive chemical that cauterizes, oxidizes, and erodes mucous membranes and skin. Generally, is prepared in solutions at a concentration of $80-90 \%$ and must be administered by a doctor. Successful treatment of CA with TCA usually requires more applications, healing has rarely occurred after a single application. TCA is a cheap, cost-effective therapeutic option that requires continuous administration. The product's destructive capacity typically extends beyond the superficial wart to the underlying viral infection, with cure rates ranging from $70 \%$ to $80 \%$ and a recurrence rate of roughly $36 \%[52,53]$. In an obstetric trial that evaluated TCA $85 \%$ solution used to treat 50 women with external genital warts, all lesions were eradicated after two to five months of treatment. In the first six months of follow-up, there was no recurrence in the group of patients studied, but in the second follow-up period of six months, nine patients presented with recurrent warts. TCA is a suggested treatment option for CA because it is associated with a low rate of morbidity and a high rate of therapeutic success [54].

\section{Cryotherapy}

Cryotherapy (Grade B) is a technique that involves destruction of the affected tissue with a freezing agent such as liquid nitrogen or nitrogen oxide. Temperatures must be extremely cold to produce permanent vascular and skin damage. This results in an inflammatory response and necrosis, followed by the elimination of the damaged cells. Cryotherapy is often effective when small 
and multiple lesions in the vulva or penis are treated. Cryotherapy is widely regarded as a very effective and cost-efficient therapy, with an injury elimination rate between $79 \%$ and $88 \%$ seen within the first three months of treatment; this indicates a more beneficial outcome than TCA [55]. Several limiting factors, such as contact time and temperature of use, can affect the efficacy of this therapy. Local ulcers, potentially permanent scars, infections, painful blisters, and skin depigmentation are all common side effects of cryotherapy, which can be more severe than with TCA. Cryotherapy has local effects and is generally the treatment for pregnant women with numerous warts [55].

\section{Electrosurgery}

Electrosurgery (Grade B) is a method that burns and destroys warts using high frequency electric currents in the form of electrocautery or thermal coagulation. Curettage is used to remove the damaged tissue. This method is especially helpful for treating smaller warts on the vulva, penis, or rectum. These procedures should not be used on large lesions because they cause permanent scars. Electrosurgery is a highly effective procedure, with a success rate of approximately $94 \%$ six weeks after treatment. These results demonstrate that electrosurgery is comparable to cryotherapy in terms of long-term efficacy. Electrosurgery is a rather painful procedure that requires local or general anesthesia; often, post-procedural soreness is the only adverse effect [56, 57].

\section{Surgical scissor excision}

Surgical scissor excision (Grade B) is one of the oldest methods of treating $\mathrm{CA}$ and has long been considered the first line of treatment. This involves the physical removal of genital warts with a scalpel or scissors and suturing healthy skin. It is associated with a success rate of up to $74 \%$, one year after the intervention. Although this procedure is regarded outdated nowadays, it is appropriate for huge warts that do not respond to conventional treatment or cause obstructions; examples include warts affecting the urinary meatus. Additionally, surgical excision remains the primary treatment option for neoplastic tumors suspected of malignant transformation that must be followed-up histopathologically. Mohs surgery is a more advanced surgical procedure for genital wart removal. Although this procedure is most commonly used to remove carcinomas, Mohs surgery consist of removing the skin in very thin layers and immediately analyzing it microscopically for abnormal features. Further slices of skin are removed in the presence of viral cell features, until healthy tissue is reached. The obvious advantage of this procedure is that it preserves the maximum amount of healthy skin and results in the appearance of minimal scars [58].

\section{$\mathrm{CO}_{2}$ laser therapy}

$\mathrm{CO}_{2}$ laser therapy (Grade $\mathrm{B}$ ) is based on the application of a concentrated infrared light beam to the target tissue, which heats and finally vaporizes it. Light's intense energy has the property to cauterize the vessels, ensuring a bleedingfree procedure. The laser beam's spatial 'concentration' enables accurate tissue excision, resulting in a very small scar and complete healing. The efficacy of $\mathrm{CO}_{2}$ therapy in treating CA remains debatable. Laser therapy has a success rate of between $23 \%$ and $52 \%$ and is regarded less successful than other surgical procedures. Rates of recurrence are increased up to $77 \%$. Side effects are generally limited to burning tissue in the vicinity of the lesion. Despite these apparent disadvantages, the laser has a substantial effect, allowing for a more thorough and effective viral treatment than is possible with other methods of surgical treatment. This approach is still preferable for pregnant women with big warts that are resistant to cryotherapy and for immunosuppressed persons [59].

\section{Therapies not generally recommended}

Due to its low efficacy and toxicity, the routine use of 5-FU, Podophyllin or IFN is not recommended for primary care [60].

\section{a Prevention}

Numerous preventive strategies can be applied to avoid HPV infection and the development of CA, including the use of condoms, however they do not give $100 \%$ protection, and there may be skin contact in other locations during sexual intercourse. Also, limiting the number of sexual partners reduces the risk of contracting the virus, but there may be infected people who have had only one sexual partner in their lifetime, but this partner may have had a history of HPV infection. The best method of prevention is sexual abstinence [33].

HPV vaccine is another option of prevention. Certain vaccines can protect individuals against HPV infection and the development of a variety of benign and malignant tumors caused by this virus family. Cervarix, Silgard or Gardasil (Table 2) are three types of safe vaccines that are utilized in the community for prevention $[61,62]$. These vaccinations are safe to give to both men and women, but do not treat illnesses already present in the host organism [63-66].

Infected patients should counsel their partner to prevent or administer appropriate treatment, because untreated genital warts can progress to malignant lesions [67].

Patients who are infected should counsel their partner on how to avoid or cure genital warts, as untreated genital warts can proceed to malignant tumors [67].

Table 2 - Types of HPV vaccines administered to the population with different age groups [61]

\begin{tabular}{|c|c|c|c|}
\hline & $\begin{array}{c}\text { Cervarix } \\
\text { (bivalent HPV vaccine) }\end{array}$ & $\begin{array}{c}\text { Gardasil } \\
\text { (4-valent HPV vaccine) }\end{array}$ & $\begin{array}{c}\text { Gardasil } 9 \\
\text { (9-valent HPV vaccine) } \\
\end{array}$ \\
\hline $\begin{array}{l}\text { Type of HPV for which the } \\
\text { vaccine provides protection }\end{array}$ & 16,18 & $\begin{array}{c}6,11 \text { (genital warts) } \\
16 \text { and } 18\end{array}$ & $\begin{array}{l}\text { 6, } 11 \text { (genital warts), } 16,18,31,33,45, \\
52 \text { and } 58\end{array}$ \\
\hline Gender and age range & $\begin{array}{l}\text { Females, } \\
\text { 9-26 years }\end{array}$ & $\begin{array}{l}\text { Males and females, } \\
9-26 \text { years }\end{array}$ & $\begin{array}{l}\text { Males and females, } 9-26 \text { years, } 27-45 \text { years } \\
\text { (not routine recommended) }\end{array}$ \\
\hline Dosing schedule & $\begin{array}{l}\text { Three-dose series: } \\
0,1,6 \text { months }\end{array}$ & $\begin{array}{l}\text { Three-dose series: } \\
0,2,6 \text { months }\end{array}$ & $\begin{array}{l}\text { Three-dose series: } \\
0,2,6 \text { months }\end{array}$ \\
\hline
\end{tabular}

HPV: Human papillomavirus. 
CA detection, on the other hand, can have a significant emotional impact on people affected. It should be emphasized, however, that different treatments can inactivate the virus or cause it to disappear spontaneously, and patients must perform various investigations that test the presence of various STDs and certain immunosuppressive pathologies. Also, infected patients should know that although wart lesions may disappear, they can still transmit the virus to sexual partners [67].

\section{Histopathological and immuno- histochemical examinations}

Histopathological (HP) examination of biopsies validates a CA diagnosis. CA is related to acanthosis, parakeratosis, papillomatosis and koilocytosis. Immunohistochemistry can be used to determine the presence of specific HPV strains or antigens. Although no clear causative links between HPV and VC infections have been established, oncogenic activation of the virus is thought to inactivate the p53 tumor suppressor gene and may promoting tumor development [68].

Histologically, VC can vary from pseudoepitheliomatous lesions to SCC. Vacuolation and the presence of keratohyalin granules in the epithelial granular layer structure are both characteristics of genital zarts, but may differ in VC $[69,70]$.

Differentiation between VC and SCC is possible based on the expression of specific oncogenes. Both are positive for immunohistochemical (IHC) labeling with anti-Ki67 or anti-p53 antibodies, but in $\mathrm{VC}$, immunoreactivity is limited to the lower $1 / 3$ of the epithelium, whereas in SCC, immunoreactivity is widespread across the epithelium [71].

Another complication of persistent HPV infection is the development of $2 / 3$ grade cervical intraepithelial neoplasia, which can lead to invasive cervical cancer in $10-20 \%$ cases of infected women [72].

Penile cancer can occur in men with HR HPV infection and a history of warty lesions; however, it is 10-fold less prevalent than cervical cancer. According to studies, infected men had a 5.9-fold increased chance of developing penile cancer compared to individuals without a history of warty lesions [73].

\section{ㅁ Case presentation}

The clinical case we report here is a 29-year-old female, without obstetric history, with a pathological history of epilepsy who was treated with Depakine (three tablets every eight hours). Atypical squamous cells of undetermined significance (ASC-US) result of liquid-based cervical cytology was identified along with the presence of five HR HPV types $(16,33,45,59,68)$ in extended genotyping. The patient stated that she was sexually abused when she was eight years old and had the first epileptic seizure and is undergoing treatment to date. Additionally, she had cauliflower warts for almost seven years that have not responded to local topical treatment and had an imbalanced life filled with intense sexual activity.

She presented in the polyclinic, to the Service of Obstetrics and Gynecology, Emergency County Hospital, Târgu Jiu, Romania, for the appearance of tumor formations in the vulvar and anorectal regions, with an onset time of roughly 6-7 years and progressive growth in size, discomfort, local pain, and leucorrhea.

Clinical examination of the patient revealed the presence of cauliflower tumors, multiple, with irregular surface, with a single implantation base on each formation, reddish white, with small areas more intensely colored, painful to the touch, in pubic, vulvar, and anorectal region (Figure 1). Following the clinical examination and performing a detailed anamnesis, the patient was hospitalized in the Clinic of Obstetrics and Gynecology to perform specialized investigations and treatment procedures.

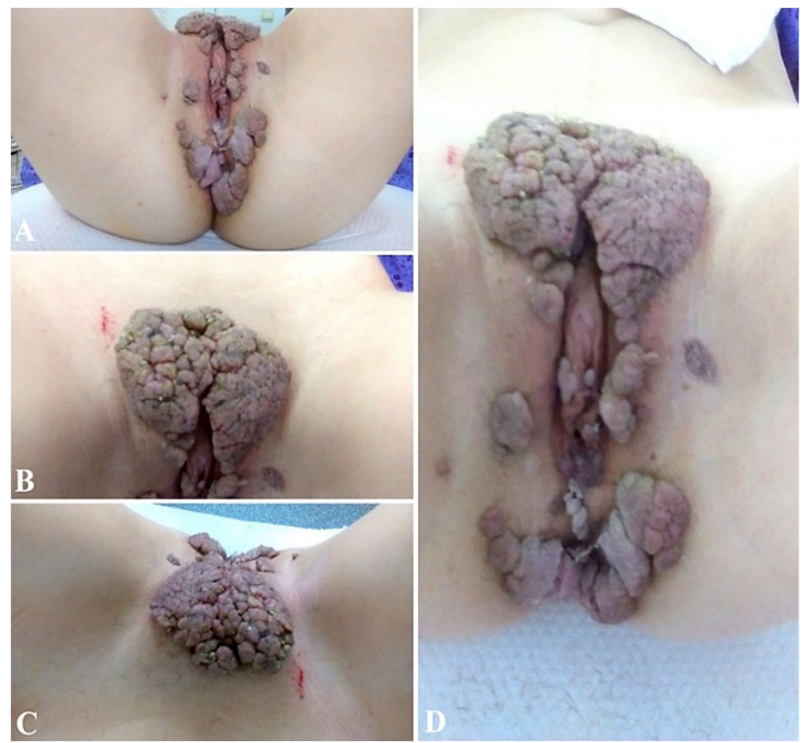

Figure 1 - (A-D) Clinical examination of the patient and observation of tumor formations with cauliflower appearance, pale white-pink color, with small areas more intensely colored, bloodless, with pubic, vulvar and anorectal localization, with multiple areas of necrosis, which bleed slightly.

At the local gynecological examination, it was found the presence of several tumor formations, of condylomatous appearance, of large dimensions, which include both labia, as well as perineum and perianal, with multiple areas of necrosis, which bled easily. At the valve examination, no lesions of the cervix were detected, macroscopically visible and no blood was lost vaginally.

The local gynecological examination revealed the presence of many tumor formations with a condylomatous form, large dimensions, involving both the labia and the perineum, and perianal regions, with multiple areas of necrosis that bled slightly. No lesions of the cervix and no vaginal bleeding were observed macroscopically during the valve examination. After performing the serological analyzes, it was decided to perform the surgical treatment, with the excision of tumor (Figure 2) and to send the tissue pieces to the Department of Pathology for the HP examination.

The processed paraffin blocks were sent to the Research Center for Microscopic Morphology and Immunology, University of Medicine and Pharmacy of Craiova, Romania.

The blocks were sectioned at $5 \mu \mathrm{m}$ with the aid of a HM350 rotary microtome equipped with a section transfer to water bath system (STS microM). 


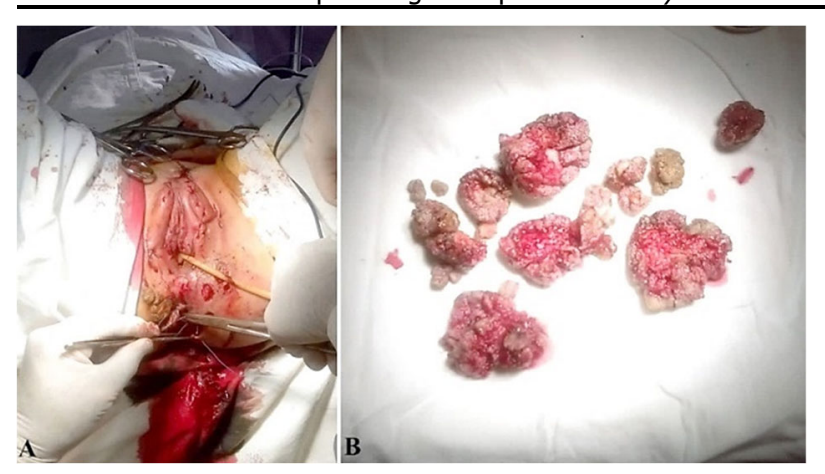

Figure 2 - (A) Intraoperative appearance of postexcisional wounds. Areas of surgical suture at the pubic, labial, vulvar and anorectal levels are observed. (B) Excised tumor formations. It is observed the cauliflower aspect, with a unique development base, with colors ranging from white-pink to more intense areas.

The slides were deparaffinized, rehydrated with successive alcohol baths with decreasing concentration of $100 \%, 96 \%$, $90 \%, 70 \%$ (five minutes each) and then with distilled water $\left(\mathrm{dH}_{2} \mathrm{O}\right)$ for 15 minutes. The sections have been stained using classical Hematoxylin-Eosin (HE) and Masson's trichrome (MT).

For IHC studies, antigenic unmasking was performed using a citrate $\mathrm{pH} 6$ or Ethylenediaminetetraacetic acid (EDTA) pH 9 solution; the tissue was inactivated with oxygenated water $\left(\mathrm{H}_{2} \mathrm{O}_{2}\right)$ (30 minutes) and non-specific endogenous sites were blocked using skim milk (30 minutes). After tissue preparation processes, the antibodies of interest were prepared in the appropriate concentrations (Table 3), and the slides were placed to $4^{\circ} \mathrm{C}$ (for 18 hours). The following day, the slides were put at room temperature, washed in phosphate-buffered saline (PBS) solution and the specific secondary antibody was applied for each immunoreaction [mouse/rabbit immunoglobulin G (IgG) antibody, VC002-025, R\&D Systems, VisUCyte Horseradish Peroxidase (HRP) Polymer] (one hour). After washing the slides in PBS to remove the secondary antibody, the slides reacted with 3,3'-Diaminobenzidine (DAB) (Dako), and the cell nuclei were stained with Hematoxylin solution. At the end of the working protocol, the slides were dehydrated in progressive alcohol baths of $70 \%, 90 \%$, $96 \%$, and $100 \%$ (five minutes each), clarified in xylene baths $(3 \times 15$ minutes/bath), and finally, the slides were mounted, so that they could be studied microscopically and stored for a long time without affecting the tissue by contact. The colored slides were scanned at a $20 \times$ lens using a Motic EasyScan equipment (Motic China Group Co., Ltd., Xiamen, China) and saved in proprietary format in a database in the Motic Digital Slide Assistant package. They were then exported as *.tiff files at full resolution for further processing.

Table 3 - Immunohistochemical panel of antibodies used by us

\begin{tabular}{ccccccc}
\hline Antibody & Manufacturer & Clone & $\begin{array}{c}\text { Antigenic } \\
\text { exposure }\end{array}$ & Secondary antibody & Dilution & Labeling \\
\hline $\begin{array}{c}\text { Anti-CK } \\
\text { AE1/AE3 }\end{array}$ & Dako & AE1/AE3 & Citrate, pH 6 & $\begin{array}{c}\text { Monoclonal mouse } \\
\text { anti-human CK }\end{array}$ & $1: 50$ & Epithelial tissues \\
\hline Anti-CK5/6 & Dako & D5/16B4 & EDTA, pH 9 & $\begin{array}{c}\text { Monoclonal mouse } \\
\text { anti-human CK5/6 }\end{array}$ & $1: 50$ & Basal cells \\
\hline Anti-CD34 & Dako & QBEnd/10 & Citrate, pH 6 & $\begin{array}{c}\text { Monoclonal mouse } \\
\text { anti-human CD34 Class II }\end{array}$ & 1:50 & Neoformed blood vessels \\
\hline Anti-p16 & Invitrogen & 1D7D2 & Citrate, pH 16 & $\begin{array}{c}\text { Monoclonal mouse } \\
\text { anti-p16 }\end{array}$ & 1:504a & $\begin{array}{c}\text { Human protein CDKN2A - present } \\
\text { in HPV infection }\end{array}$ \\
\hline Anti-Ki67 & Dako & MIB-1 & EDTA, pH 9 & $\begin{array}{c}\text { Monoclonal mouse } \\
\text { anti-human Ki67 }\end{array}$ & $1: 50$ & $\begin{array}{c}\text { Cells in division in the G1, S2 G2 } \\
\text { and M phase }\end{array}$ \\
\hline Anti-p63 & Dako & 4A4 & Citrate, pH 6 & $\begin{array}{c}\text { Monoclonal mouse } \\
\text { anti-human p63 protein }\end{array}$ & $1: 50$ & Nuclear marker \\
\hline Anti-p53 & Dako & DO-7 & EDTA, pH 9 & $\begin{array}{c}\text { Monoclonal mouse } \\
\text { anti-human p53 protein }\end{array}$ & $1: 50$ & Nuclear marker \\
\hline Anti-CD68 & Dako & KP1 & Citrate, pH 6 & $\begin{array}{c}\text { Monoclonal mouse } \\
\text { anti-human CD68 }\end{array}$ & $1: 100$ & Macrophages \\
\hline Anti-CD3 & Dako & Polyclonal & Citrate, pH 6 & $\begin{array}{c}\text { Polyclonal rabbit } \\
\text { anti-human CD3 }\end{array}$ & $1: 50$ & T-lymphocytes \\
\hline Anti-CD20 & Dako & L26 & Citrate, pH 6 & $\begin{array}{c}\text { Monoclonal mouse } \\
\text { anti-human CD20cy }\end{array}$ & $1: 50$ & B-lymphocytes \\
\hline
\end{tabular}

CD: Cluster of differentiation; CDKN2A: Cyclin-dependent kinase inhibitor 2A; CK: Cytokeratin; EDTA: Ethylenediaminetetraacetic acid; HPV: Human papillomavirus.

On HE slides, these benign lesions have a fibrovascular core covered by squamous epithelium. Next to the vessels in the stroma are also present chronic inflammatory cells. The squamous epithelium changes are acanthosis, parakeratosis, papillomatosis and koilocytosis. Koilocytes are focal and usually present in the upper layers of the epithelium. Koilocytic changes include increased nuclear size and wrinkling, perinuclear halo, and presence of mitotic figures (Figures 3 and 4A). When MT staining was used, it was revealed that the tumor mucosa has a lot of collagen fibers intensely colored in blue (Figure 4B).

IHC studies revealed certain particular aspects of $C A$, so we observed intense reactivity with anti-cytokeratin
(CK) AE1/AE3 antibody throughout the thickness of the epithelium (Figure 5).

The anti-CK5/6 antibody (Figure 6A) was used to detect the basal layers of the HPV-infected epithelium, the site of virus proliferation and the presence of HPV infection was confirmed by intense epithelial immunolabeling with the anti-p16 $6^{\text {INK4a }}$ antibody (Figure 6B).

Vessels within the stroma of the tumor were identified using an anti-cluster of differentiation (CD) 34 antibody which reacted with vascular endothelial cells present in the fibrovascular cores (Figure 7A). Anti-Ki67 antibody was used to mark tumor epithelial cells during division, particularly in the basal layers (Figure 7B). 


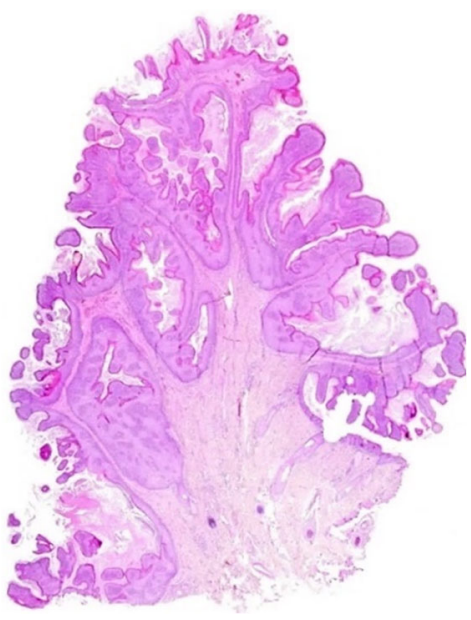

Figure 3 - Frontal histological section by CA fragment. It is observed the unique base of implantation of the tumor with arborescent macroscopic appearance and the epithelium with acanthosis and undulated surface. HE staining, $\times 20$. CA: Condyloma acuminatum; HE: Hematoxylin-Eosin.
The dividing cells showed basal and parabasal epithelial hyperreactivity, as evidenced by the anti-p63 antibody; This antibody revealed a pan-epithelial reaction (Figure 8A). Additionally, a thicker epithelium with acanthosis, an undulated surface and low positivity in the basal layer is observed when the anti-p53 antibody is used. This antibody highlights few basal epithelial cells that were affected by HPV and showed inactivation of the tumor suppressor gene (Figure 8B).

The immune system's involvement in lesion evolution is demonstrated by highlighting macrophage cells with an anti-CD68 antibody in the structure of the tumor epithelium and underlying tissue (Figure 9A), T-lymphocytes with an anti-CD3 antibody in the structure of the tumor epithelium and underlying tissue with perivascular conglomeration (Figure 9B), and B-cells with an anti-CD20 antibody in the structure of the tumor epithelium and underlying tissue in a relatively low number (Figure 9C).

HP examination revealed condylomatous features, inflammatory process with koilocytic atypia.
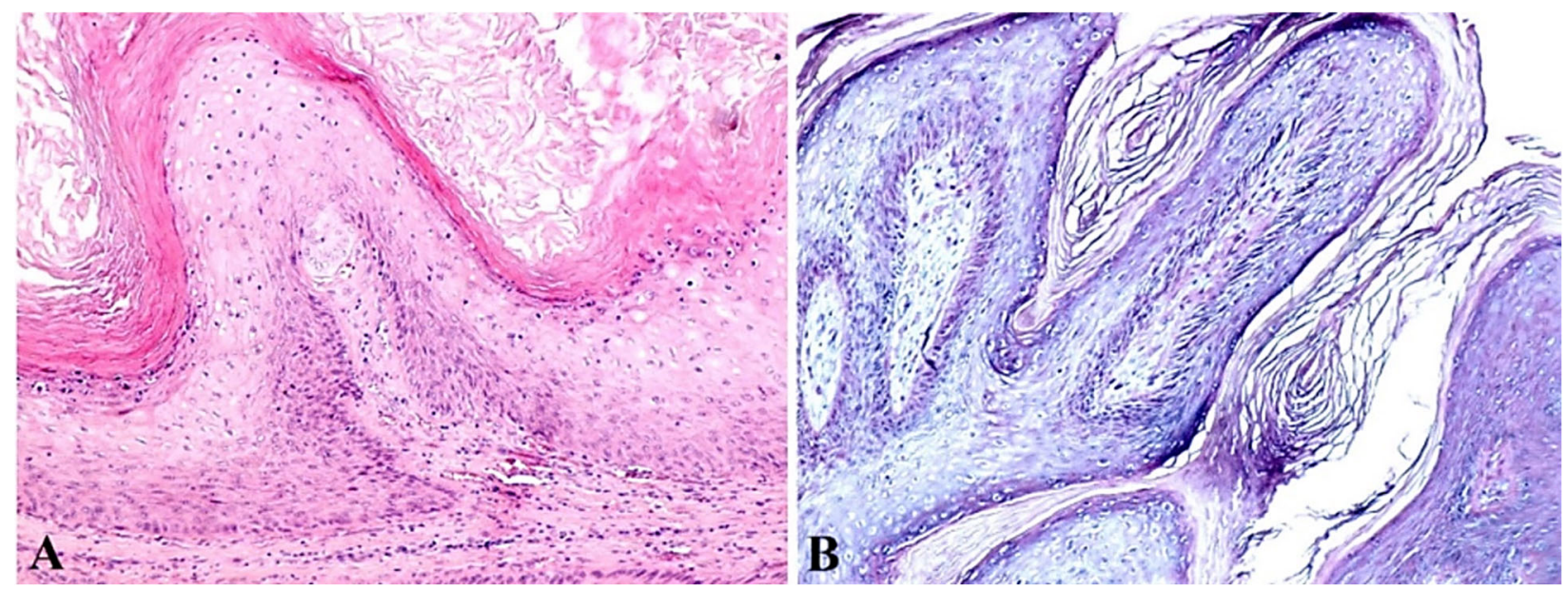

Figure 4 - Histological section by CA fragment: (A) Note the thickened epithelium, with the presence of koilocytes especially in the superficial layers and the parakeratosis; (B) The thickened epithelium is observed, with the presence of koilocytes especially in the superficial layers, of parakeratosis, with an increased density of collagen fibers in the stroma. HE staining: $(A) \times 100$. MT staining: $(B) \times 100$. CA: Condyloma acuminatum; HE: Hematoxylin-Eosin; MT: Masson's trichrome.

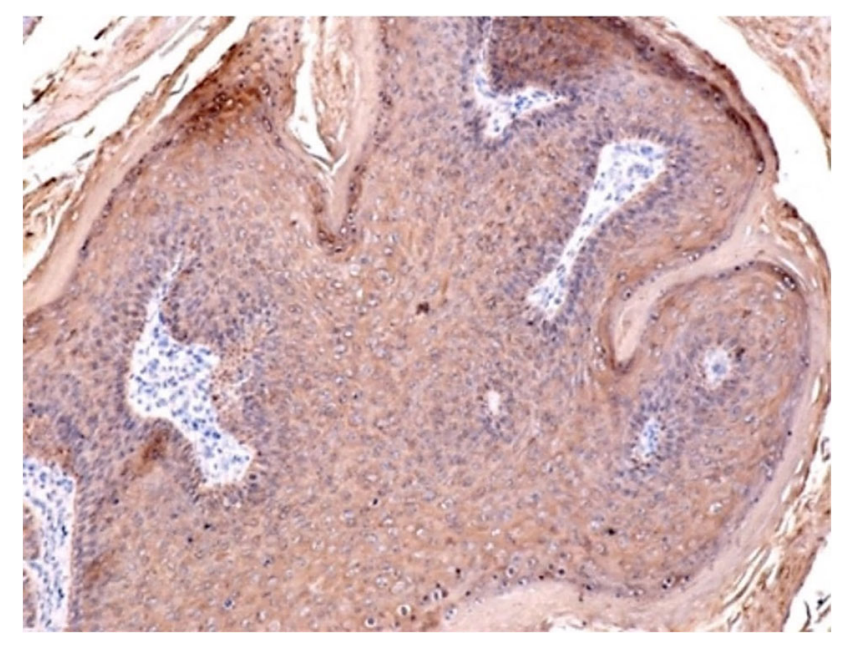

Figure 5 - Histological section by CA fragment. The thickened epithelium is observed, with the presence of koilocytes especially in the superficial layers and the intense epithelial immunoreactivity. IHC staining with anti-CK AE1/AE3 antibody, $\times 100$. CA: Condyloma acuminatum; CK: Cytokeratin; IHC: Immunohistochemical. 


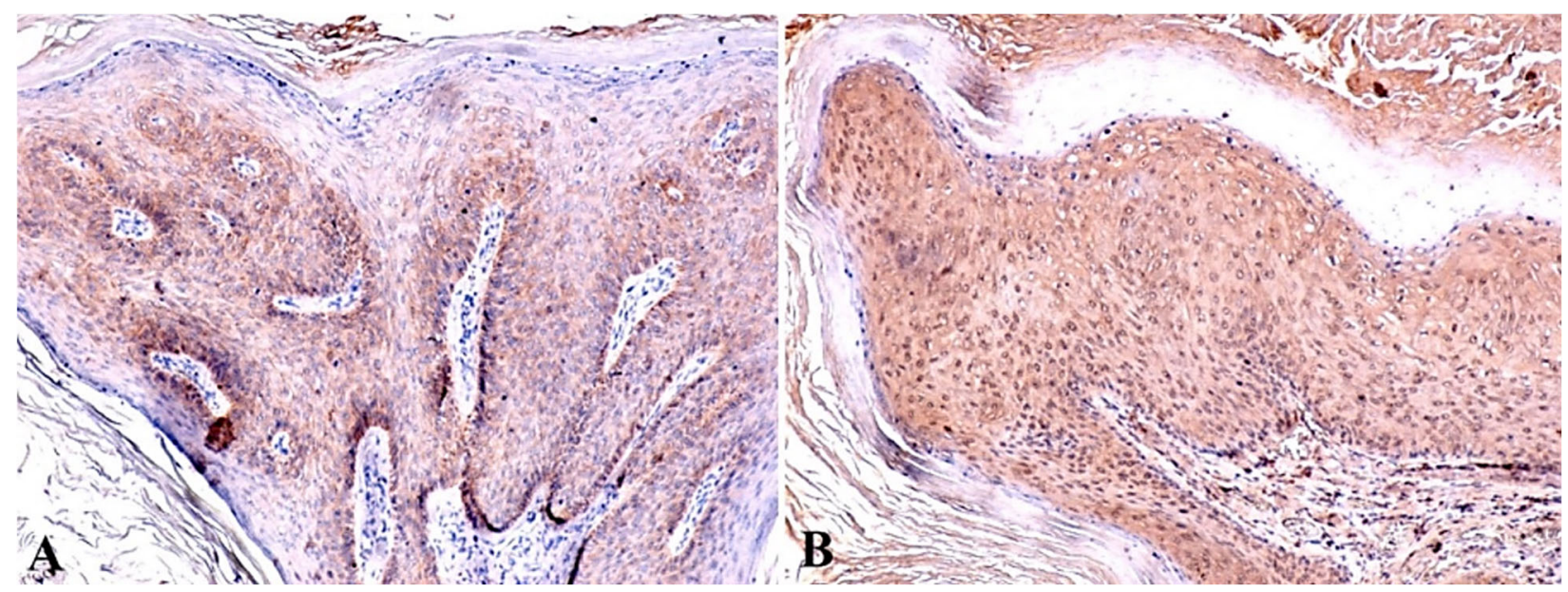

Figure 6 - Histological section by CA fragment: (A) The thickened epithelium is observed, with the presence of koilocytes especially in the superficial layers, and the intense epithelial immunoreactivity at the level of the basal layers; (B) The thickened epithelium is observed, with the presence of koilocytes especially in the superficial layers and intense epithelial immunoreactivity to the anti-p16 antibody. IHC staining with anti-CK5/6 antibody: $(A) \times 100$. IHC staining with antip16 antibody: (B) $\times 100$. CA: Condyloma acuminatum, CK: Cytokeratin; IHC: Immunohistochemical.

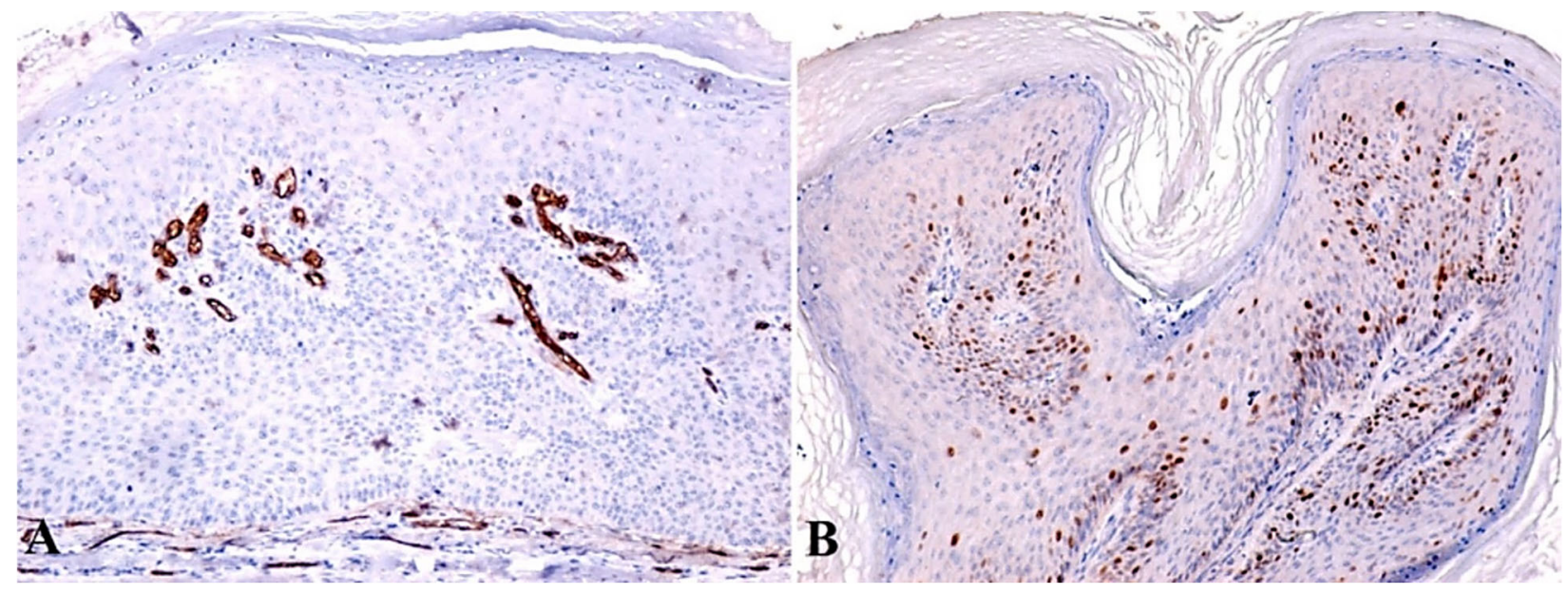

Figure 7 - Histological section by CA fragment: (A) Vessels within the fibrovascular core highlighted by the anti-CD34 antibody that marks vascular endothelial cells; (B) The unique base of implantation of the tumor formation is observed, the epithelium with thickened structure, acanthosis, with undulated surface, with positivity in the basal layer at the immunoreaction with the anti-Ki67 antibody. IHC staining with anti-CD34 antibody: $(A) \times 100$. IHC staining with antiKi67 antibody: (B) $\times 100$. CA: Condyloma acuminatum; CD34: Cluster of differentiation 34; IHC: Immunohistochemical.

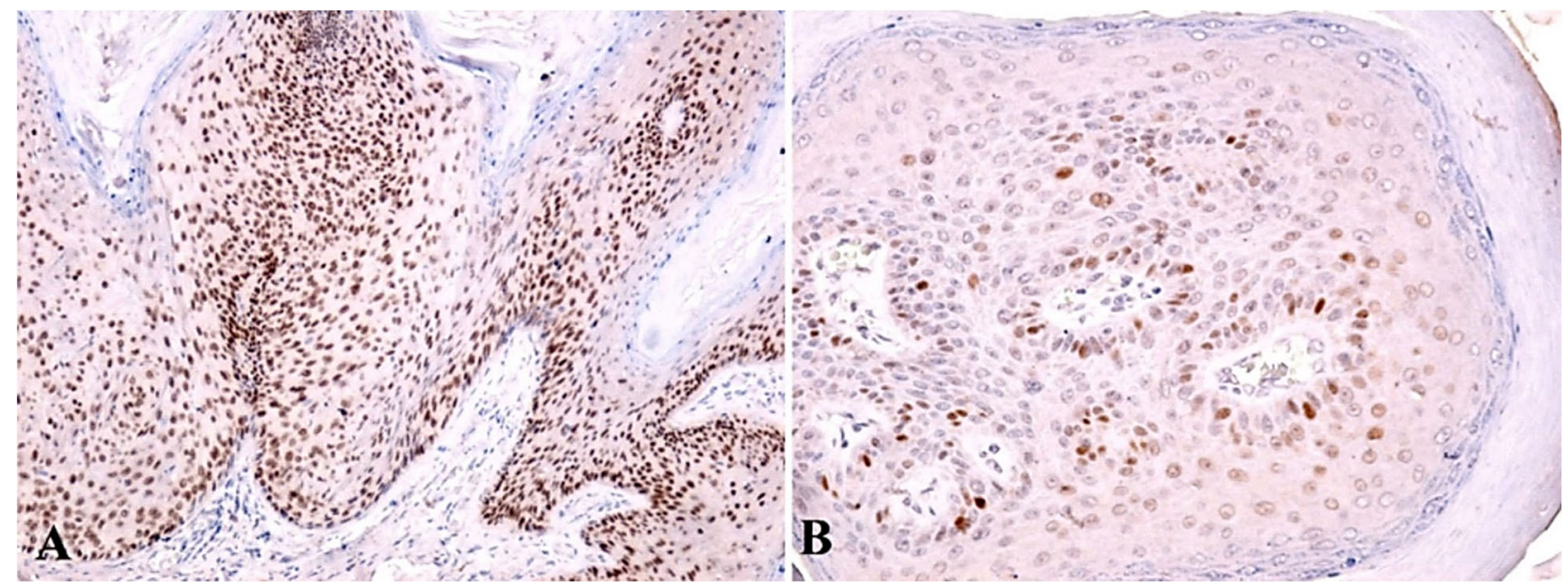

Figure 8 - Histological section by CA fragment: (A) There is a pan-epithelial hyperreactivity, highlighted by the antip63 antibody that marks the cells in division; (B) Rare epithelial cells positive for immunoreaction with anti-p53 antibody is observed. IHC staining with anti-p63 antibody: $(A) \times 100$. IHC staining with anti-p53 antibody: (B) $\times 200$. CA: Condyloma acuminatum; IHC: Immunohistochemical. 


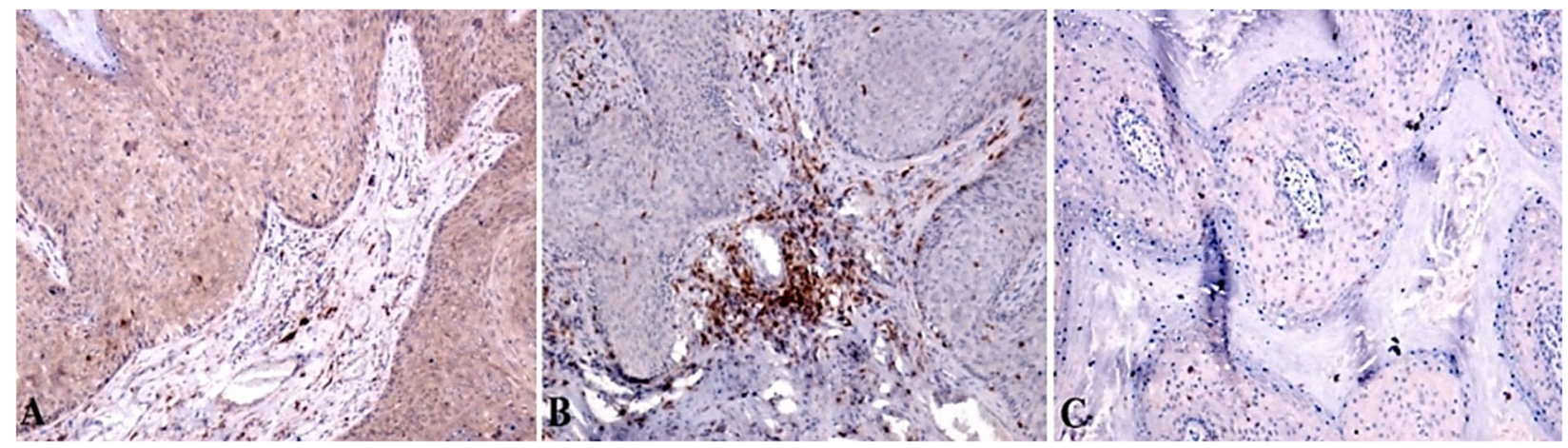

Figure 9 - Histological sections through the tumor formation that highlights the involvement of the immune system in the lesion evolution: (A) Macrophages are identified both in the thickness of the tumor epithelium, especially in the basal layers and stroma; (B) T-lymphocytes are identified both in the thickness of the tumor epithelium, especially in the basal layers and stroma, with perivascular distribution; (C) Rare B-lymphocytes are identified, both in the thickness of the tumor epithelium and stroma. IHC staining with anti-CD68 antibody: $(A) \times 100$. IHC staining with anti-CD3 antibody: (B) $\times 100$. IHC staining with anti-CD20 antibody: $(C) \times 100$. CD: Cluster of differentiation; IHC: Immunohistochemical.

\section{$\square$ Discussions}

Lately, CAs have become more frequent and may be associated with malignancies, due to the spread of HPV throughout the population because of more sexual partners and a lack of condom use [74]. There are over $50 \mathrm{HPV}$ strains, but most often, those involved in the occurrence of CA are HPV 6, 11, 16, and 18 strains. The first two types are generally associated with benign tumors, and the last two with severe forms of dysplasia and even with SCC $[74,75]$.

Strauss et al. [76] confirmed the presence of HPV in the tumor structure using electromicroscopy, in 1949. Oriel \& Almeida [77] used the electron microscope to find viral particles in the CA structure [77]. In 1971, Oriel [26] stated that this pathology is sexually transmitted, just like gonorrhea [26]. CA occurs through microlesions produced during intercourse, is exacerbated during pregnancy. It can be spread by a simple touch from one area of the skin to another [78]. In the case presented by us, the patient had been confirmed to have an HPV 6 infection for several years but did not follow any local, excisional or topical treatment, leading to the development of condylomatous areas with significant evolution.

Generally, the diagnosis of CA is made clinically, based on the distinctive symptomatic and macroscopic characteristics of the disease, and HPV genotyping is routinely indicated. The definite diagnosis can only be made with the biopsied or excised tissue samples. HP examination is extremely important to be able to differentiate $\mathrm{CA}$ from other tumors even some malignant ones such as SCC, which can coexist. Danish studies have shown that HPV has an increased risk of developing malignancies. In cases with marked atypia, it is necessary to perform special IHC staining to exclude a malignant lesion [79].

The treatment applied can be both local, topical, and surgical excision [36]. In this case, surgical treatment was appropriate because the patient complains of discomfort during defecation and sexual contact, pain caused by compression of the giant tumor and the desire to resume to her sexual life, being a young patient. The surgical treatment was the excision of the tumor formation and suturing the wounds to minimize the possibility of recurrence due to autoinoculation.

From a HP point of view, CA was studied a long time ago, with lesions such as acanthosis hyperkeratosis, parakeratosis, and the presence of modified keratinocytes, called koilocytes [80-82]. The performed studies described several types of lesions, partially achieving clinical and HP correlations [83-85]. Analysis of numerous biopsies revealed that there are several phases of CA: growth phase, the full-expression phase, and the regressive or persistent phase. These have been described histopathologically as cutaneous skin papillomas by Hamada et al. [86].

It has been observed that only flat warts can regress spontaneously due to immunity, through early infiltration of macrophages and T-lymphocytes into the dermis and subsequently transepithelial. CD4+ cells are the most active, while CD8+ cells are particularly active in lesions that do not regress [87-91]. The case described by us had immunoreactivity for macrophages immunohistochemically labeled with anti-CD68 antibody and T-lymphocytes immunohistochemically labeled with anti-CD3 antibody, particularly in the dermis, with a low number of intraepithelial cells, which may indicate that the tumor became vegetative and was unable to regress spontaneously. In our study, CD20+ B-lymphocytes were present intratumorally in a very low number.

In 1993, Okabayashi et al. [92] managed to describe CA by using rabbits, as proliferative lesions, with dividing and regressive cells, with a lot of intradermal and intraepithelial inflammatory cells.

In 1994, Coleman et al. [16] published their first study with patients who had regressive warts and detected an extensive subepithelial inflammatory infiltrate.

Randomized studies have developed a protocol for HP analysis of CA, aiming to identify the evolutionary phase by the presence of koilocytes, hyperplasia, acanthosis, and hyperkeratosis [93]. The case described by us presented all these lesions and they were emphasized by the classical HE staining.

The example presented here did not spontaneously regress, despite the presence of T-lymphocytes in the dermis, but keratinocytes were detected in varying degrees of cell 
division, which supported tumor growth and development. These proliferative cells were immunohistochemically labeled with anti-Ki67 antibody. Ki67 antigen is a proliferation-associated nuclear protein [93]. The degree of cell proliferation indicates that the tumor was constantly developing.

The anti-p63 antibody recognizes a protein encoded by the tumor protein p63 (TP63) gene [94] and is a member of the p53 family of transcription factors. It was used to identify cells with dysplastic and neoplastic transformation potential, as demonstrated by numerous studies. Overexpression of the TP63 gene is associated with inactivation of tumor suppressor genes in vulvar cancers [95]. In our case, we observed intense immunoreactivity, which demonstrates the potential for malignant transformation. P63 also contributes to the differential diagnosis of other types of malignancies, as it is strongly positive for SCC and negative for mall cell carcinoma or adenocarcinoma [96].

The TP53 gene encodes the p53 tumor protein, also known as the genome guardian, which prevents genome alterations, being classified as a tumor suppressor gene [97-102]. The p53 gene is the most often mutated gene in cancer $(>50 \%)$ and plays a critical role in the development of neoplasms [103]. In pathologies caused by HPV infections, such as CA, where is encoded a gene, E6, which binds the p53 protein and inactivates it. This phenomenon occurs synchronously with the inactivation of the pRb cell cycle regulator by the HPV-specific E7 protein, leading to cell division and the appearance of warts. HR HPVs, especially 16 and 18, can transform a benign wart into a dysplastic or neoplastic one [104]. In our case of CA, the cellular reactivity for p53 was quite weak, which shows that the tumor had a low degree of evolution to malignancy, but this does not guarantee longterm stability or the absence of subsequent transformation.

Another tumor suppressor is p16, known as p16 ${ }^{\mathrm{INK} 4 \mathrm{a}}$. It is a cyclin-dependent kinase inhibitor $2 \mathrm{~A}$ (CDKN2A), and also a protein that slows cell division and cell cycle progression from $\mathrm{G} 1$ phase to $\mathrm{S}$ phase. The deletion of a small portion of the CDKN2A gene leads to p16 inactivation, accelerates the cell cycle, and leads to several cancers $[105,106]$. P16 is also used as a biomarker in diagnosing high-grade cervical lesions, SCC, cervical cancer, and vulvar cancer. Cancers that overexpress p16 are generally caused by HPV, and those that poorly express p16 are caused by other factors [107]. It is a frequently utilized marker in gynecological pathology, cytoplasmic and nuclear overexpression of p16 is highly related with HPV infection in genital SCC [108]. We observed a significant immunohistochemistry reactivity in our case of CA, indicating HPV infection and the degree of progression to high-grade lesions.

CK AE1/AE3 is a cocktail of CKs $1-8,10,14-16$, and 19, except for CK17 and CK18, that is used to identify carcinomas, their invasion, and metastases. Additionally, it distinguishes myofibroblasts from smooth muscle cells [109]. In CA, it marked the whole epithelium intensely and did a differential diagnosis with another type of tumor.

CK5/6 is used in IHC studies to label basal or myoepithelial cells within the structure of various organs, being positive in SCC, basal cell carcinoma, transitional cell carcinoma, thymoma, and salivary gland tumors, allowing for the differential diagnosis of benign and malignant lesions [110]. CA's epithelial origin is also confirmed by the positivity of CK5/6 in the basal layer of epithelial cells.

Also, intratumoral vascularity, proliferating cells and the presence of p16 and epithelial CK immunostaining contributed to increased tumor growth and progression. In our case of CA, we used the anti-CD34 antibody to highlight the endothelial cells of the blood vessels and implicitly the vascular density that supported the tumor evolution. CD34 is a transmembrane phosphoglycoprotein that was first described in hematopoietic stem cells and was later used as a vascular marker in neoangiogenesis [111-115].

\section{ㅁ Conclusions}

CA is a common pathology that can be prevented by using several preventive measures against the transmission of HPV. Prompt therapy may limit the development of tumors. Clinical features and symptoms might have a significant impact on the patient's ability to live a normal life. HP and IHC examinations are important for diagnostic and may reveal various tumor features, such as the presence of increased vascularization, degree of cell proliferation, epithelial affiliation, inactivation of tumor suppressor genes, presence of HPV infection and involvement of the cellmediated immune system, which can accelerate tumor evolution and development from benignity to malignancy.

\section{Conflict of interests}

The authors declare that they have no conflict of interests.

\section{Acknowledgments}

Microscopic images have been acquired in the Research Center for Microscopic Morphology and Immunology, University of Medicine and Pharmacy of Craiova, Romania (Manager: Laurenţiu Mogoantă, Professor, MD, PhD).

\section{Authors' contribution}

Damian Diţescu and Anca-Maria Istrate-Ofiţeru equally contributed to this article.

\section{References}

[1] Mayeaux EJ Jr, Dunton C. Modern management of external genital warts. J Low Genit Tract Dis, 2008, 12(3):185-192. https:// doi.org/10.1097/LGT.0b013e31815dd4b4 PMID: 18596459

[2] Insinga RP, Dasbach EJ, Elbasha EH. Epidemiologic natural history and clinical management of human papillomavirus (HPV) disease: a critical and systematic review of the literature in the development of an HPV dynamic transmission model. BMC Infect Dis, 2009, 9:119. https://doi.org/10.1186/14712334-9-119 PMID: 19640281 PMCID: PMC2728100

[3] Scheinfeld N, Lehman DS. An evidence-based review of medical and surgical treatments of genital warts. Dermatol Online J, 2006, 12(3):5. PMID: 16638419

[4] Fleischer AB Jr, Parrish CA, Glenn R, Feldman SR. Condylomata acuminata (genital warts): patient demographics and treating physicians. Sex Transm Dis, 2001, 28(11):643-647. https:// doi.org/10.1097/00007435-200111000-00006 PMID: 11677386

[5] Koutsky LA, Galloway DA, Holmes KK. Epidemiology of genital human papillomavirus infection. Epidemiol Rev, 1988, 10:122163. https://doi.org/10.1093/oxfordjournals.epirev.a036020 PMID: 2852116 
[6] Moore RA, Edwards JE, Hopwood J, Hicks D. Imiquimod for the treatment of genital warts: a quantitative systematic review. BMC Infect Dis, 2001, 1:3. https://doi.org/10.1186/1471-23 34-1-3 PMID: 11401728 PMCID: PMC32301

[7] Cates W Jr. Estimates of the incidence and prevalence of sexually transmitted diseases in the United States. American Social Health Association Panel. Sex Transm Dis, 1999, 26(4 Suppl): S2-S7. https://doi.org/10.1097/00007435-199904001-00002 PMID: 10227693

[8] Batista CS, Atallah AN, Saconato H, da Silva EM. 5-FU for genital warts in non-immunocompromised individuals. Cochrane Database Syst Rev, 2010, 2010(4):CD006562. https://doi.org/ 10.1002/14651858.CD006562.pub2 PMID: 20393949 PMCID: PMC7206224

[9] Markowitz LE, Dunne EF, Saraiya M, Lawson HW, Chesson H Unger ER; Centers for Disease Control and Prevention (CDC); Advisory Committee on Immunization Practices (ACIP). Quadrivalent human papillomavirus vaccine: recommendations of the Advisory Committee on Immunization Practices (ACIP). MMWR Recomm Rep, 2007, 56(RR-2):1-24. PMID: 17380109

[10] Weinstock H, Berman S, Cates W Jr. Sexually transmitted diseases among American youth: incidence and prevalence estimates, 2000. Perspect Sex Reprod Health, 2004, 36(1): 6-10. https://doi.org/10.1363/psrh.36.6.04 PMID: 14982671

[11] Mougin C, Dalstein V, Prétet JL, Gay C, Schaal JP, Riethmuller D. [Epidemiology of cervical papillomavirus infections. Recent knowledge]. Presse Med, 2001, 30(20):1017-1023. PMID: 11433694

[12] Sanclemente G, Gill DK. Human papillomavirus molecular biology and pathogenesis. J Eur Acad Dermatol Venereol, 2002, 16(3):231-240. https://doi.org/10.1046/j.1473-2165.2002. 00419.x PMID: 12195562

[13] Veldhuijzen NJ, Snijders PJ, Reiss P, Meijer CJ, van de Wijgert JH. Factors affecting transmission of mucosal human papillomavirus. Lancet Infect Dis, 2010, 10(12):862-874. https:// doi.org/10.1016/S1473-3099(10)70190-0 PMID: 21075056

[14] Gormley RH, Kovarik CL. Human papillomavirus-related genital disease in the immunocompromised host: Part I. J Am Acad Dermatol, 2012, 66(6):867.e1-867.e14; quiz 881-882. https:// doi.org/10.1016/j.jaad.2010.12.050 PMID: 22583720

[15] British Association for Sexual Health and HIV (BASHH). UK National Guidelines on the Management of Anogenital Warts 2015. Clinical Effectiveness Group, BASHH, April 2015. https:// www.bashhguidelines.org/media/1075/uk-national-guidelineon-warts-2015-final.pdf

[16] Juckett G, Hartman-Adams H. Human papillomavirus: clinical manifestations and prevention. Am Fam Physician, 2010, 82(10):1209-1213. PMID: 21121531

[17] Cardoso JC, Calonje E. Cutaneous manifestations of human papillomaviruses: a review. Acta Dermatovenerol Alp Pannonica Adriat, 2011, 20(3):145-154. PMID: 22131115

[18] Koutsky L. Epidemiology of genital human papillomavirus infection. Am J Med, 1997, 102(5A):3-8. https://doi.org/10. 1016/s0002-9343(97)00177-0 PMID: 9217656

[19] Koliopoulos G, Arbyn M, Martin-Hirsch P, Kyrgiou M, Prendiville W, Paraskevaidis E. Diagnostic accuracy of human papillomavirus testing in primary cervical screening: a systematic review and meta-analysis of non-randomized studies. Gynecol Oncol, 2007, 104(1):232-246. https://doi.org/10.1016/j.ygyno. 2006.08.053 PMID: 17084886

[20] Yanofsky VR, Patel RV, Goldenberg G. Genital warts: a comprehensive review. J Clin Aesthet Dermatol, 2012, 5(6): 25-36. PMID: 22768354 PMCID: PMC3390234

[21] Jenkins D, Tay SK, McCance DJ, Campion MJ, Clarkson PK, Singer A. Histological and immunocytochemical study of cervical intraepithelial neoplasia (CIN) with associated HPV 6 and HPV 16 infections. J Clin Pathol, 1986, 39(11):1177-1180. https://doi.org/10.1136/jcp.39.11.1177 PMID: 3025266 PMCID: PMC1140758

[22] Winer RL, Lee SK, Hughes JP, Adam DE, Kiviat NB, Koutsky LA. Genital human papillomavirus infection: incidence and risk factors in a cohort of female university students. Am J Epidemiol, 2003, 157(3):218-226. https://doi.org/10.1093/aje/kwf180 PMID: 12543621

[23] Baken LA, Koutsky LA, Kuypers J, Kosorok MR, Lee SK, Kiviat NB, Holmes KK. Genital human papillomavirus infection among male and female sex partners: prevalence and type- specific concordance. J Infect Dis, 1995, 171(2):429-432. https:// doi.org/10.1093/infdis/171.2.429 PMID: 7844382

[24] Ho GY, Bierman R, Beardsley L, Chang CJ, Burk RD. Natural history of cervicovaginal papillomavirus infection in young women. N Engl J Med, 1998, 338(7):423-428. https://doi.org/ 10.1056/NEJM199802123380703 PMID: 9459645

[25] Coleman N, Birley HD, Renton AM, Hanna NF, Ryait BK, Byrne M, Taylor-Robinson D, Stanley MA. Immunological events in regressing genital warts. Am J Clin Pathol, 1994, 102(6):768-774. https://doi.org/10.1093/ajcp/102.6.768 PMID: 7801889

[26] Oriel JD. Natural history of genital warts. $\mathrm{Br} \mathrm{J}$ Vener Dis, 1971, 47(1):1-13. https://doi.org/10.1136/sti.47.1.1 PMID: 5550858 PMCID: PMC1048137

[27] Dubina M, Goldenberg G. Viral-associated nonmelanoma skin cancers: a review. Am J Dermatopathol, 2009, 31(6):561573. https://doi.org/10.1097/DAD.0b013e3181a58234 PMID: 19590418

[28] Schwartz RA. Verrucous carcinoma of the skin and mucosa. J Am Acad Dermatol, 1995, 32(1):1-21; quiz 22-24. https:// doi.org/10.1016/0190-9622(95)90177-9 PMID: 7822496

[29] Lacey CJN, Woodhall SC, Wikstrom A, Ross J. 2012 European Guideline for the management of anogenital warts. J Eur Acad Dermatol Venereol, 2012, 27(3):e263-e270. https://doi.org/10. 1111/j.1468-3083.2012.04493.x PMID 22409368

[30] Chin-Hong PV, Husnik M, Cranston RD, Colfax G, Buchbinder S, Da Costa M, Darragh T, Jones D, Judson F, Koblin B, Mayer KH, Palefsky JM. Anal human papillomavirus infection is associated with HIV acquisition in men who have sex with men. AIDS, 2009, 23(9):1135-1142. https://doi.org/10.1097/QAD.0b013 e32832b4449 PMID: 19390418 PMCID: PMC4577294

[31] Sinclair KA, Woods CR, Sinal SH. Venereal warts in children. Pediatr Rev, 2011, 32(3):115-121; quiz 121. https://doi.org/ 10.1542/pir.32-3-115 PMID: 21364015

[32] Forcier M, Musacchio N. An overview of human papillomavirus infection for the dermatologist: disease, diagnosis, management, and prevention. Dermatol Ther, 2010, 23(5):458-476. https:// doi.org/10.1111/j.1529-8019.2010.01350.x PMID: 20868401

[33] Schlecht HP, Fugelso DK, Murphy RK, Wagner KT, Doweiko JP, Proper J, Dezube BJ, Panther LA. Frequency of occult highgrade squamous intraepithelial neoplasia and invasive cancer within anal condylomata in men who have sex with men. Clin Infect Dis, 2010, 51(1):107-110. https://doi.org/10.1086/ 653426 PMID: 20482370 PMCID: PMC4460603

[34] Flagg EW, Schwartz R, Weinstock H. Prevalence of anogenital warts among participants in private health plans in the United States, 2003-2010: potential impact of human papillomavirus vaccination. Am J Public Health, 2013, 103(8):1428-1435. https://doi.org/10.2105/AJPH.2012.301182 PMID: 23763409 PMCID: PMC4007878

[35] Follin SL, Charland SL. Acute pain management: operative or medical procedures and trauma. Ann Pharmacother, 1997, 31(9):1068-1076. https://doi.org/10.1177/106002809703100 917 PMID: 9296248

[36] von Krogh G. Podophyllotoxin for condylomata acuminata eradication. Clinical and experimental comparative studies on Podophyllum lignans, colchicine, and 5-fluorouracil. Acta Derm Venereol Suppl (Stockh), 1991, 98:31-48. PMID: 7046325

[37] Mohanty KC. The cost effectiveness of treatment of genital warts with podophyllotoxin. Int J STD AIDS, 1994, 5(4):253256. https://doi.org/10.1177/095646249400500405 PMID: 7948154

[38] Lacey CJN, Goodall RL, Tennvall GR, Maw R, Kinghorn GR, Fisk PG, Barton S, Byren I; Perstop Pharma Genital Warts Clinical Trial Group. Randomised controlled trial and economic evaluation of podophyllotoxin solution, podophyllotoxin cream, and podophyllin in the treatment of genital warts. Sex Transm Infect, 2003, 79(4):270-275. https://doi.org/10.1136/sti.79.4. 270 PMID: 12902571 PMCID: PMC1744726

[39] Greenberg MD, Rutledge LH, Reid R, Berman NR, Precop SL, Elswick RK Jr. A double-blind, randomized trial of $0.5 \%$ podofilox and placebo for the treatment of genital warts in women. Obstet Gynecol, 1991, 77(5):735-739. PMID: 2014088

[40] Edwards A, Atma-Ram A, Thin RN. Podophyllotoxin $0.5 \% \mathrm{~V}$ podophyllin $20 \%$ to treat penile warts. Genitourin Med, 1988, 64(4):263-265. https://doi.org/10.1136/sti.64.4.263 PMID: 3169757 PMCID: PMC1194230 
[41] Brown DR, Schroeder JM, Bryan JT, Stoler MH, Fife KH. Detection of multiple human papillomavirus types in condylomata acuminata lesions from otherwise healthy and immunosuppressed patients. J Clin Microbiol, 1999, 37(10):3316-3322. https://doi.org/10.1128/JCM.37.10.3316-3322.1999 PMID: 10488198 PMCID: PMC85555

[42] Perry CM, Lamb HM. Topical imiquimod: a review of its use in genital warts. Drugs, 1999, 58(2):375-390. https://doi.org/ 10.2165/00003495-199958020-00017 PMID: 10473026

[43] Bilu D, Sauder DN. Imiquimod: modes of action. Br J Dermatol, 2003, 149(Suppl 66):5-8. https://doi.org/10.1046/j.0366-077 x.2003.05628.x PMID: 14616337

[44] Sauder DN, Skinner RB, Fox TL, Owens ML. Topical imiquimod $5 \%$ cream as an effective treatment for external genital and perianal warts in different patient populations. Sex Transm Dis, 2003, 30(2):124-128. https://doi.org/10.1097/00007435-200 302000-00006 PMID: 12567169

[45] Arany I, Tyring SK, Stanley MA, Tomai MA, Miller RL, Smith MH, McDermott DJ, Slade HB. Enhancement of the innate and cellular immune response in patients with genital warts treated with topical imiquimod cream 5\%. Antiviral Res, 1999, 43(1): 55-63. https://doi.org/10.1016/s0166-3542(99)00033-9 PMID: 10480263

[46] Gollnick H, Barasso R, Jappe U, Ward K, Eul A, Carey-Yard M, Milde K. Safety and efficacy of imiquimod $5 \%$ cream in the treatment of penile genital warts in uncircumcised men when applied three times weekly or once per day. Int J STD AIDS, 2001, 12(1):22-28. PMID: 11177478

[47] Quist SR, Gollnick HP. Imiquimod 3.75\% cream (Zyclara) for the treatment of actinic keratoses. Expert Opin Pharmacother 2011, 12(3):451-461. https://doi.org/10.1517/14656566.2011. 549128 PMID: 21254950

[48] Baker DA, Ferris DG, Martens MG, Fife KH, Tyring SK, Edwards L, Nelson A, Ault K, Trofatter KF, Liu T, Levy S, Wu J. Imiquimod $3.75 \%$ cream applied daily to treat anogenital warts: combined results from women in two randomized, placebo-controlled studies. Infect Dis Obstet Gynecol, 2011, 2011:806105. https://doi.org/10.1155/2011/806105 PMID: 21876641 PMCID: PMC3162968

[49] Rosen T, Nelson A, Ault K. Imiquimod cream $2.5 \%$ and $3.75 \%$ applied once daily to treat external genital warts in men. Cutis, 2015, 96(4):277-282. PMID: 26682290

[50] Ahn WS, Yoo J, Huh SW, Kim CK, Lee JM, Namkoong SE, Bae SM, Lee IP. Protective effects of green tea extracts (polyphenon E and EGCG) on human cervical lesions. Eur J Cancer Prev, 2003, 12(5):383-390. https://doi.org/10.1097/ 00008469-200310000-00007 PMID: 14512803

[51] Sutherland BA, Rahman RMA, Appleton I. Mechanisms of action of green tea catechins, with a focus on ischemia-induced neurodegeneration. J Nutr Biochem, 2006, 17(5):291-306. https://doi.org/10.1016/j.jnutbio.2005.10.005 PMID: 16443357

[52] Abdullah AN, Walzman M, Wade A. Treatment of externa genital warts comparing cryotherapy (liquid nitrogen) and trichloroacetic acid. Sex Transm Dis, 1993, 20(6):344-345. PMID: 8108758

[53] Godley MJ, Bradbeer CS, Gellan M, Thin RN. Cryotherapy compared with trichloroacetic acid in treating genital warts. Genitourin Med, 1987, 63(6):390-392. https://doi.org/10.1136/ sti.63.6.390 PMID: 3323028 PMCID: PMC1194123

[54] Kodner CM, Nasraty S. Management of genital warts. Am Fam Physician, 2004, 70(12):2335-2342. PMID: 15617297

[55] Stone KM, Becker TM, Hadgu A, Kraus SJ. Treatment of external genital warts: a randomised clinical trial comparing podophyllin, cryotherapy, and electrodesiccation. Genitourin Med, 1990, 66(1):16-19. https://doi.org/10.1136/sti.66.1.16 PMID: 2179111 PMCID: PMC1194434

[56] Scoular A. Choosing equipment for treating genital warts in genitourinary medicine clinics. Genitourin Med, 1991, 67(5): 413-419. https://doi.org/10.1136/sti.67.5.413 PMID: 1822975 PMCID: PMC1194744

[57] Duus BR, Philipsen T, Christensen JD, Lundvall F, Søndergaard J. Refractory condylomata acuminata: a controlled clinical trial of carbon dioxide laser versus conventional surgical treatment. Genitourin Med, 1985, 61(1):59-61. https://doi.org/ 10.1136/sti.61.1.59 PMID: 3936774 PMCID: PMC1011758

[58] Pennington BE, Leffell DJ. Mohs micrographic surgery: established uses and emerging trends. Oncology (Williston
Park), 2005, 19(9):1165-1171, discussion 1171-1172, 1175. PMID: 16255133

[59] Carrozza PM, Merlani GM, Burg G, Hafner J. $\mathrm{CO}_{2}$ laser surgery for extensive, cauliflower-like anogenital condylomata acuminata: retrospective long-term study on 19 HIV-positive and 45 HIV-negative men. Dermatology, 2002, 205(3):255259. https://doi.org/10.1159/000065844 PMID: 12399673

[60] von Krogh G, Lacey CJ, Gross G, Barrasso R, Schneider A; European Course on HPV Associated Pathology (ECHPV); European Branch of the International Union against Sexually Transmitted Infection and the European Office of the World Health Organization. European Guideline for the management of anogenital warts. Int J STD AIDS, 2001, 12(Suppl 3):40-47. https://doi.org/10.1258/0956462011924100 PMID: 11589796

[61] Markowitz LE, Dunne EF, Saraiya M, Chesson HW, Curtis CR, Gee J, Bocchini JA Jr, Unger ER; Centers for Disease Control and Prevention (CDC). Human papillomavirus vaccination: recommendations of the Advisory Committee on Immunization Practices (ACIP). MMWR Recomm Rep, 2014, 63(RR-05): 1-30. PMID: 25167164

[62] Schwartz JL. HPV vaccination's second act: promotion, competition, and compulsion. Am J Public Health, 2010, 100(10):1841-1844. https://doi.org/10.2105/AJPH.2010.193 060 PMID: 20724671 PMCID: PMC2936995

[63] Handler MZ, Handler NS, Majewski S, Schwartz RA. Human papillomavirus vaccine trials and tribulations: clinical perspectives. J Am Acad Dermatol, 2015, 73(5):743-756; quiz 757-758. https://doi.org/10.1016/j.jaad.2015.05.040 PMID: 26475534

[64] Handler NS, Handler MZ, Majewski S, Schwartz RA. Human papillomavirus vaccine trials and tribulations: vaccine efficacy. J Am Acad Dermatol, 2015, 73(5):759-767; quiz 767-768. https://doi.org/10.1016/j.jaad.2015.05.041 PMID: 26475535

[65] Markowitz LE, Hariri S, Lin C, Dunne EF, Steinau M, McQuillan G, Unger ER. Reduction in human papillomavirus (HPV) prevalence among young women following HPV vaccine introduction in the United States, National Health and Nutrition Examination Surveys, 2003-2010. J Infect Dis, 2013, 208(3):385-393. https://doi.org/10.1093/infdis/jit192 PMID: 23785124

[66] Petrosky E, Bocchini JA Jr, Hariri S, Chesson H, Curtis CR, Saraiya M, Unger ER, Markowitz LE; Centers for Disease Control and Prevention (CDC). Use of 9-valent human papillomavirus (HPV) vaccine: updated HPV vaccination recommendations of the Advisory Committee on Immunization Practices. MMWR Morb Mortal Wkly Rep, 2015, 64(11):300304. PMID: 25811679 PMCID: PMC4584883

[67] Gross G. [Differential diagnosis of condylomata acuminata. Indication for histopathology]. Hautarzt, 2009, 60(6):465-471. https://doi.org/10.1007/s00105-008-1694-9 PMID: 19452137

[68] Scheffner M, Werness BA, Huibregtse JM, Levine AJ, Howley PM. The E6 oncoprotein encoded by human papillomavirus types 16 and 18 promotes the degradation of p53. Cell, 1990, 63(6): 1129-1136. https://doi.org/10.1016/0092-8674(90)90409-8 PMID: 2175676

[69] Brownstein MH, Shapiro L. Verrucous carcinoma of skin: epithelioma cuniculatum plantare. Cancer, 1976, 38(4):17101716. https://doi.org/10.1002/1097-0142(197610)38:4<1710 ::aid-cncr2820380444>3.0.co;2-x PMID: 991089

[70] Batsakis JG, Hybels R, Crissman JD, Rice DH. The pathology of head and neck tumors: verrucous carcinoma, Part 15. Head Neck Surg, 1982, 5(1):29-38. https://doi.org/10.1002/hed.28 90050107 PMID: 6757187

[71] Drachenberg CB, Blanchaert R, loffe OB, Ord RA, Papadimitriou JC. Comparative study of invasive squamous cell carcinoma and verrucous carcinoma of the oral cavity: expression of bcl-2, p53, and Her-2/neu, and indexes of cell turnover. Cancer Detect Prev, 1997, 21(6):483-489. PMID: 9398988

[72] Stanley M. Pathology and epidemiology of HPV infection in females. Gynecol Oncol, 2010, 117(2 Suppl):S5-S10. https:// doi.org/10.1016/j.ygyno.2010.01.024 PMID: 20304221

[73] Maden C, Sherman KJ, Beckmann AM, Hislop TG, Teh CZ, Ashley RL, Daling JR. History of circumcision, medical conditions, and sexual activity and risk of penile cancer. J Natl Cancer Inst, 1993, 85(1):19-24. https://doi.org/10.1093/jnci/85.1.19 PMID: 8380060

[74] Luchtefeld MA. Perianal condylomata acuminata. Surg Clin North Am, 1994, 74(6):1327-1338. https://doi.org/10.1016/ s0039-6109(16)46484-4 PMID: 7985068 
[75] Eron LJ. Human papillomavirus and anogenital disease. In: Gorbach SL, Bartlett JG, Blacklow NR (eds). Infectious diseases. W.B. Saunders Co., Philadelphia, 1992, 852-856. https://www. worldcat.org/title/infectious-diseases/oclc/751369033?referer= di\&ht=edition

[76] Mudrikova T, Jaspers C, Ellerbroek P, Hoepelman A. HPVrelated anogenital disease and HIV infection: not always 'ordinary' condylomata acuminata. Neth J Med, 2008, 66(3):98-102. PMID: 18349464

[77] Oriel JD, Almeida JD. Demonstration of virus particles in human genital warts. Br J Vener Dis, 1970, 46(1):37-42. https://doi. org/10.1136/sti.46.1.37 PMID: 4313975 PMCID: PMC1048021

[78] Oriel JD. Anal warts and anal coitus. Br J Vener Dis, 1971 47(5):373-376. https://doi.org/10.1136/sti.47.5.373 PMID: 5123626 PMCID: PMC1048228

[79] Blomberg M, Friis S, Munk C, Bautz A, Kjaer SK. Genital warts and risk of cancer: a Danish study of nearly 50000 patients with genital warts. J Infect Dis, 2012, 205(10):1544-1553. https://doi.org/10.1093/infdis/jis228 PMID: 22427679

[80] Meisels A, Fortin R, Roy M. Condylomatous lesions of the cervix. II. Cytologic, colposcopic and histopathologic study. Acta Cytol, 1977, 21(3):379-390. PMID: 268117

[81] Dias EP. Papilomavírus humano: aspectos biológicos, clínicos e morfológicos [Human papillomavirus: biological, clinical and morphological aspects]. J Bras Med, 1993, 64(6):206-217, 210-212, 217. https://pesquisa.bvsalud.org/portal/resource/ $\mathrm{pt} / \mathrm{lil}-182681$

[82] Myint SH, Shaw AV. Laboratory identification of human papillomavirus infection. In: Mindel A (ed). Genital warts: human papillomavirus infection. Edward Arnold Publisher, London-Boston, 1995, 35-52. https://www.ncbi.nlm.nih.gov/ nlmcatalog/9500758

[83] Sykes NL Jr. Condyloma acuminatum. Int J Dermatol, 1995, 34(5):297-302. https://doi.org/10.1111/j.1365-4362.1995.tb0 3607.x PMID: 7541783

[84] Rock B, Shah KV, Farmer ER. A morphologic, pathologic, and virologic study of anogenital warts in men. Arch Dermatol, 1992, 128(4):495-500. PMID: 1316102

[85] Gross G, Ikenberg H, Gissmann L, Hagedorn M. Papillomavirus infection of the anogenital region: correlation between histology, clinical picture, and virus type. Proposal of a new nomenclature. J Invest Dermatol, 1985, 85(2):147-152. https:// doi.org/10.1111/1523-1747.ep12276576 PMID: 2991390

[86] Hamada M, Oyamada T, Yoshikawa H, Yoshikawa T, Itakura C Histopathological development of equine cutaneous papillomas. J Comp Pathol, 1990, 102(4):393-403. https://doi.org/10.1016/ s0021-9975(08)80161-2 PMID: 2164051

[87] Tagami H, Ogino A, Takigawa M, Imamura S, Ofuji S. Regression of plane warts following spontaneous inflammation. A histopathological study. Br J Dermatol, 1974, 90(2):147-154. https://doi.org/10.1111/j.1365-2133.1974.tb06378.x PMID: 4819132

[88] Tagami H, Takigawa M, Ogino A, Imamura S, Ofugi S. Spontaneous regression of plane warts after inflammation: clinical and histologic studies in 25 cases. Arch Dermatol, 1977, 113(9):1209-1213. PMID: 900963

[89] Tagami H, Oguchi M, Ofuji S. The phenomenon of spontaneous regression of numerous flat warts: immunohistological studies. Cancer, 1980, 45(10):2557-2563. https://doi.org/10.1002/10 97-0142(19800515)45:10<2557::aid-cncr2820451014>3.0.co; 2-Z PMID: 7378991

[90] Aiba S, Rokugo M, Tagami H. Immunohistologic analysis of the phenomenon of spontaneous regression of numerous flat warts. Cancer, 1986, 58(6):1246-1251. https://doi.org/10.1002/ 1097-0142(19860915)58:6<1246::aid-cncr2820580612>3.0.co; 2-e PMID: 3017534

[91] Bishop PE, McMillan A, Fletcher S. An immunohistological study of spontaneous regression of condylomata acuminata. Genitourin Med, 1990, 66(2):79-81. https://doi.org/10.1136/ sti.66.2.79 PMID: 2140338 PMCID: PMC1194465

[92] Okabayashi M, Angell MG, Budgeon LR, Kreider JW. Shope papilloma cell and leukocyte proliferation in regressing and progressing lesions. Am J Pathol, 1993, 142(2):489-496. PMID: 8434644 PMCID: PMC1886746

[93] Scholzen T, Gerdes J. The Ki-67 protein: from the known and the unknown. J Cell Physiol, 2000, 182(3):311-322. https://
doi.org/10.1002/(SICI)1097-4652(200003)182:3<311::AID-J CP1>3.0.CO;2-9 PMID: 10653597

[94] Yang A, Kaghad M, Wang Y, Gillett E, Fleming MD, Dötsch V, Andrews NC, Caput D, McKeon F. p63, a p53 homolog at 3q27-29, encodes multiple products with transactivating, deathinducing, and dominant-negative activities. Mol Cell, 1998, 2(3): 305-316. https://doi.org/10.1016/s1097-2765(00)80275-0 PMID: 9774969

[95] Rotondo JC, Borghi A, Selvatici R, Magri E, Bianchini E, Montinari E, Corazza M, Virgili A, Tognon M, Martini F. Hypermethylation-induced inactivation of the IRF6 gene as a possible early event in progression of vulvar squamous cell carcinoma associated with lichen sclerosus. JAMA Dermatol, 2016, 152(8): 928-933. https://doi.org/10.1001/jamadermatol.2016.1336 PMID: 27223861

[96] Zhang H, Liu J, Cagle PT, Allen TC, Laga AC, Zander DS. Distinction of pulmonary small cell carcinoma from poorly differentiated squamous cell carcinoma: an immunohistochemical approach. Mod Pathol, 2005, 18(1):111-118. https:// doi.org/10.1038/modpathol.3800251 PMID: 15309021

[97] Toufektchan E, Toledo F. The guardian of the genome revisited: p53 downregulates genes required for telomere maintenance, DNA repair, and centromere structure. Cancers (Basel), 2018, 10(5):135. https://doi.org/10.3390/cancers10050135 PMID: 29734785 PMCID: PMC5977108

[98] Matlashewski G, Lamb P, Pim D, Peacock J, Crawford L, Benchimol S. Isolation and characterization of a human p53 cDNA clone: expression of the human p53 gene. EMBO J, 1984, 3(13):3257-3262. PMID: 6396087 PMCID: PMC557846

[99] Isobe M, Emanuel BS, Givol D, Oren M, Croce CM. Localization of gene for human p53 tumour antigen to band 17p13. Nature, 1986, 320(6057):84-85. https://doi.org/10.1038/320084a0 PMID: 3456488

[100] Kern SE, Kinzler KW, Bruskin A, Jarosz D, Friedman P, Prives C, Vogelstein B. Identification of p53 as a sequencespecific DNA-binding protein. Science, 1991, 252(5013):17081711. https://doi.org/10.1126/science.2047879 PMID: 2047879

[101] McBride OW, Merry D, Givol D. The gene for human p53 cellular tumor antigen is located on chromosome 17 short arm (17p13). Proc Natl Acad Sci U S A, 1986, 83(1):130-134. https://doi.org/10.1073/pnas.83.1.130 PMID: 3001719 PMCID: PMC322805

[102] Bourdon JC, Fernandes K, Murray-Zmijewski F, Liu G, Diot A, Xirodimas DP, Saville MK, Lane DP. p53 isoforms can regulate p53 transcriptional activity. Genes Dev, 2005, 19(18):2122-2137. https://doi.org/10.1101/gad.1339905 PMID: 16131611 PMCID: PMC1221884

[103] Surget S, Khoury MP, Bourdon JC. Uncovering the role of p53 splice variants in human malignancy: a clinical perspective. Onco Targets Ther, 2013, 7:57-68. https://doi.org/10.2147/ OTT.S53876 PMID: 24379683 PMCID: PMC3872270

[104] Angeletti PC, Zhang L, Wood C. The viral etiology of AIDSassociated malignancies. Adv Pharmacol, 2008, 56:509-557. https://doi.org/10.1016/S1054-3589(07)56016-3 PMID: 18086422 PMCID: PMC2149907

[105] Nobori T, Miura K, Wu DJ, Lois A, Takabayashi K, Carson DA. Deletions of the cyclin-dependent kinase-4 inhibitor gene in multiple human cancers. Nature, 1994, 368(6473):753-756. https://doi.org/10.1038/368753a0 PMID: 8152487

[106] Stone S, Jiang P, Dayananth $\mathrm{P}$, Tavtigian SV, Katcher $\mathrm{H}$ Parry D, Peters G, Kamb A. Complex structure and regulation of the P16 (MTS1) locus. Cancer Res, 1995, 55(14):29882994. PMID: 7606716

[107] Liggett WH Jr, Sidransky D. Role of the $p 16$ tumor suppressor gene in cancer. J Clin Oncol, 1998, 16(3):1197-1206. https:// doi.org/10.1200/JCO.1998.16.3.1197 PMID: 9508208

[108] Cioffi-Lavina M, Chapman-Fredricks J, Gomez-Fernandez C, Ganjei-Azar P, Manoharan M, Jorda M. P16 expression in squamous cell carcinomas of cervix and bladder. Appl Immunohistochem Mol Morphol, 2010, 18(4):344-347. https:// doi.org/10.1097/PAI.0b013e3181d2bbd7 PMID: 20571342

[109] Sidey K, Kobic A, Vidal NY. Identifying squamous cell carcinoma and cytokeratin-derived amyloid with pan-cytokeratin AE1/AE3 during Mohs micrographic surgery. JAAD Case Rep, 2020, 6(8):776-779. https://doi.org/10.1016/j.jdcr.2020.06.027 PMID: 32760776 PMCID: PMC7390831 
[110] Chu PG, Weiss LM. Expression of cytokeratin $5 / 6$ in epithelial neoplasms: an immunohistochemical study of 509 cases. Mod Pathol, 2002, 15(1):6-10. https://doi.org/10.1038/mod pathol.3880483 PMID: 11796835

[111] Simmons DL, Satterthwaite AB, Tenen DG, Seed B. Molecular cloning of a CDNA encoding CD34, a sialomucin of human hematopoietic stem cells. J Immunol, 1992, 148(1):267-271. PMID: 1370171

[112] Satterthwaite AB, Burn TC, Le Beau MM, Tenen DG. Structure of the gene encoding CD34, a human hematopoietic stem cell antigen. Genomics, 1992, 12(4):788-794. https://doi.org/10. 1016/0888-7543(92)90310-o PMID: 1374051

[113] Civin Cl, Strauss LC, Brovall C, Fackler MJ, Schwartz JF, Shaper JH. Antigenic analysis of hematopoiesis. III. A hematopoietic progenitor cell surface antigen defined by a monoclonal antibody raised against KG-1a cells. J Immunol, 1984, 133(1): 157-165. PMID: 6586833

[114] Sidney LE, Branch MJ, Dunphy SE, Dua HS, Hopkinson A. Concise review: evidence for CD34 as a common marker for diverse progenitors. Stem Cells, 2014, 32(6):1380-1389. https://doi.org/10.1002/stem.1661 PMID: 24497003 PMCID: PMC4260088

[115] Oliveira BM, Pinto A, Correia A, Ferreira PG, Vilanova M, Teixeira L. Characterization of myeloid cellular populations in mesenteric and subcutaneous adipose tissue of HolsteinFriesian cows. Sci Rep, 2020, 10(1):1771. https://doi.org/ 10.1038/s41598-020-58678-0 PMID: 32019985 PMCID: PMC7000716

\section{Corresponding authors}

Gabriela-Camelia Roşu, Teaching Assistant, MD, PhD, Department of Histology, University of Medicine and Pharmacy of Craiova, 2 Petru Rareş Street, 200349 Craiova, Romania; Phone +40766-313 097, e-mail: nicola_camelia92@yahoo.com

Ilona Mihaela Liliac, MD, PhD Student, Department of Histology, University of Medicine and Pharmacy of Craiova, 2 Petru Rareş Street, 200349 Craiova, Romania; Phone +40749-059 100, e-mail: ilona.mihaela.liliac@gmail.com

Received: January 30, 2021

Accepted: December 7, 2021 